MARZENA MATLA

Instytut Historii Uniwersytetu

im. Adama Mickiewicza w Poznaniu

\title{
CARMEN PATRIUM BOGURODZICA - CZAS POWSTANIA, KONTEKST HISTORYCZNY I INSPIRACJE
}

\author{
Tekst Bogurodzicy i dotychczasowy stan badań
}

Bogurodzica to niewątpliwie jeden z najbardziej kontrowersyjnych i najdłużej dyskutowanych zabytków naszej literatury średniowiecznej w języku polskim. W dotychczasowych badaniach rozważano już niemal wszystkie aspekty związane z jej powstaniem, budową, wzorcami, funkcjonowaniem, co zaowocowało obszerną literaturą przedmiotu ${ }^{1}$. Celem niniejszego artykułu jest ponowna próba odpowiedzi na pytanie o czas i okoliczności powstania najstarszej polskiej pieśni religijnej, a w dalszej kolejności ustosunkowanie się do kwestii potencjalnych wpływów czeskich na jej kształt lub funkcjonowanie.

Zacznijmy od przypomnienia, iż w znanym tekście Bogurodzicy, liczącym w zależności od redakcji od dwóch do dwudziestu kilku zwrotek, badacze wyróżniają trzy części składowe. Pierwsze dwie zwrotki, które będą nas tu interesować, to część najstarsza, do której dołączono następnie pieśń wielkanocną (zwrotki 3-6), dalej pieśń pasyjną (7-15) oraz kolejne zwrotki poświęcone różnym świętym, zawierające też modlitwę na koronację itd. ${ }^{2}$

${ }^{1}$ Zestawienie dotychczasowej literatury m.in. Bibliografia literatury polskiej „,Nowy Korbut", t. 1: Piśmiennictwo staropolskie, oprac. R. Pollak i in., Warszawa 1963, s. 190-197; 〈http://staropolska.pl/sredniowiecze/poezja_religijna/bogurodzica/XIX.html〉(dostęp: 20 VII 2013); T. Michałowska, Leksykon literatury polskiego średniowiecza, Warszawa 2011, s.133-138.

${ }^{2} \mathrm{Na}$ co zgadza się większość uczonych, por. przykładowo K. Heck, Uwagi krytyczne nad najstarszymi tekstami i kompozycja pieśni Bogurodzica, Kraków 1904 (odbitka RWFilol AU, t. 40), s. 5, 13 n.; A. Brückner, Spór o „Bogurodzicę”, „Pamiętnik Literacki” (dalej: Pam. Lit.) 3, 1904, s. 587; T. Lehr-Spławiński, Język polski. Pochodzenie, powstanie, rozwój, Warszawa 1978, s. 136-138; J. Woronczak, Wstęp filologiczny, w: Bogurodzica, oprac. idem, wstęp jęz. E. Ostrowska, wstęp muzykolog. H. Feicht, Wrocław 1962, s. 11 nn.; J. Krzyżanowski, 
Rękopiśmienny przekaz pieśni jest stosunkowo późny, pochodzi bowiem z XV w. Najstarszy tekst w postaci dwóch pierwszych zwrotek (z nutami) został wpisany na wewnętrznej stronie tylnej okładki do przechowywanego obecnie w Bibliotece Jagiellońskiej kodeksu nr 1619³. Sam rękopis (zawierający zbiór kazań) należał wedle adnotacji (k. 218) do księdza Macieja z Grochowa, wikariusza kościoła parafialnego w Kcyni w diecezji gnieźnieńskiej. Jest on też pisarzem całego kodeksu, z którego część pierwszą ukończono w 1407 r., cały zaś rękopis, jak przypuszcza Adam Chmiel, do końca 1408 r. ${ }^{4}$ Najpewniej w 1409 r. został oprawiony, samą zaś kartę, na której znajduje się Bogurodzica, wklejono już do oprawionego kodeksu, po czym wpisano tekst ${ }^{5}$. Co istotne, wklejki te ze względu na ich cechy wiąże się z osobą księdza Macieja z Grochowa; wprawdzie bowiem sama Bogurodzica wpisana została inną ręką, jednak na jej odwrocie A. Chmiel odkrył kopię mandatu Mikołaja Strzeszkowica, kanonika i oficjała kapituły gnieźnieńskiej, wydanego w Gnieźnie w 1405 r., którego jednym z odbiorców był autor kodeksu' ${ }^{6}$.W rezultacie badacz ten przyjmuje, iż Bogurodzice $\mathrm{w}$ wersji rękopisu nr 1619 wpisano w 1409 r. lub po tym roku, choć daty tej,jego zdaniem, nie należy zbytnio przesuwać, gdyż cechy pisma Bogurodzicy łączą się z wiekiem XIV, co sugeruje, iż pisarz zachowanej wersji pieśni przepisywał ją ze starszego oryginału i powielał cechy pisma tegoż oryginału ${ }^{7}$. Odmiennie sądził Korneli Heck, który czternastowieczne cechy pisma tłumaczył dobą uczenia się sztuki pisania przez pisarza tekstu pieśni, samo zaś wpisa-

Znowu o „Bogurodzicy”, w: Z polskich studiów slawistycznych, seria 2, cz. 2: Nauka o literaturze, red. J. Magnuszewski, Warszawa 1963, s. 7; T. Michałowska, Średniowiecze, Warszawa 1997, s. 280 n.; W. Wydra, Dzieje legendy o św. Wojciechu autorze Bogurodzicy, w: Święty Wojciech $w$ tradycji i kulturze europejskiej, red. K. Śmigiel, Gniezno 1992, s. 191 n. Nieco inne zaszeregowanie, choć z uznaniem za najstarsze dwóch pierwszych strof, zob. J. Łoś, w: Bogurodzica. Pierwszy polski hymn narodowy, wyd. i kom. J. Łoś, Lublin 1922, s. 5. Łączność obu pierwszych strof kwestionuje np. Paweł Kocikowski (Dwie pierwsze zwrotki Bogurodzicy dwoma odrębnymi utworami, „Zeszyty Naukowe Uniwersytetu Mikołaja Kopernika w Toruniu. Nauki humanistyczno-społeczne", z. 12: Filologia polska, z. 5, 1965, s. 69-78), który wskazując na różnice treści i kompozycji pomiędzy nimi, uznaje, że utwory początkowo były odrębnymi pieśniami, może dwóch różnych autorów. Sądzę jednak, że wskazywane przez badaczy powiązanie zabytku z obecnym w sztuce motywem deesis (por. niżej) dobrze tłumaczy zróżnicowaną tematykę strof; inne argumenty zestawia Ewa Ostrowska, 0 artyźmie polskich średniowiecznych zabytków językowych, Kraków 1967, s. 38 n.

${ }^{3}$ A. Chmiel, Uwagi archiwalno-paleograficzne nad pieśnia Bogurodzica w rękopisie Biblioteki Jagiellońskiej nr. 1619, Kraków 1904 (odbitka RWFilol AU, t. 40), s. 45-56, tu 45; M. A.Janicki, Bogurodzica, w: Na znak świetnego zwycięstwa. W sześćsetna rocznicę bitwy pod Grunwaldem, red. nauk. D. Nowacki, t. 2: Noty katalogowe, Kraków 2010, nr 94, s. 177 n.

${ }^{4}$ A. Chmiel, op. cit., s. 46 n.; K. Heck, op. cit., s. 7 n.

${ }^{5}$ A. Chmiel, op. cit., s. 52-53; por. K. Heck, op. cit., s. 9 n.

${ }^{6}$ A. Chmiel, op. cit., s. 49-51; por. K. Heck, op. cit., s. 8 nn.

${ }^{7}$ A. Chmiel, op. cit., s. 54-55; o pisarzach zob. też M. A. Janicki, op. cit., s. 177 n. 
nie miało być efektem wzrostu jej popularności po bitwie pod Grunwaldem w okresie 1410-1415 r. ${ }^{8}$ Kolejne przekazy pochodzą z XV i XVI w., drugi chronologicznie jest rękopis nr 408 z BJ z 1408 r., który zawiera już 13 zwrotek, przy czym wpisano je po 1408 r. (może w pierwszej połowie $\mathrm{XV}$ w. $)^{9}$. Jak zauważono, odnotowanie w różnych częściach kraju w tym samym czasie świadczy o szerokim rozpowszechnieniu pieśni w tradycji ustnej (choć też o nieustabilizowaniu tekstu) ${ }^{10}$.

o śpiewaniu przez rycerstwo polskie Bogurodzicy w bitwie pod Grunwaldem donosi Cronica conflictus, powstała najpóźniej w początku roku $1411^{11}$, następnie Jan Długosz, nazywając ją carmen patrium ${ }^{12}$, oraz inne źródła relacjonujące te wydarzenia ${ }^{13}$. Długosz jej śpiewanie wspomina

${ }^{8}$ K. Heck, op. cit., s. 11 n.

${ }^{9}$ Ibidem, s. 14; J. Woronczak, Tropy i sekwencje w literaturze polskiej do połowy XVI wieku, Pam. Lit. 43, 1952, z. 1-2, odbitka Wrocław 1952, s. 349; Bogurodzica, s. 97 nn.; wedle Stanisława Urbańczyka przed 1420-1430, zob. idem, „Bogurodzica”. Problem czasu powstania i tła kulturowego, Pam. Lit. 69, 1978, z. 1, przedruk w: idem, Prace z dziejów języka polskiego, Wrocław 1979, s. 146 (cyt. ost. wyd.).

${ }^{10}$ T. Michałowska, Średniowiecze, s. 278.

${ }^{11}$ Po przemowie króla „omnes unanimiter cum fletu Boga rodzycza cantare coeperunt et ad bellum processerunt", Cronica conflictus Wladislai Regis Poloniae cum Cruciferis Anno Christi 1410, wyd. Z. Celichowski, Poznań 1911, s. 24; Kronika konfliktu Władysława króla polskiego z Krzyżakami w roku pańskim 1410, przeł. J. Danka, A. Nadolski, Olsztyn 1983, s. 11. Dzieło to, stanowiące oficjalną wersję wydarzeń pod Grunwaldem, opierało się na dobrych informacjach (zapewne naocznego świadka), spisane przez duchownego z otoczenia królewskiego. Brak zgody, czy był to ówczesny sekretarz królewski Zbigniew Oleśnicki, podkanclerzy Mikołaj Trąba, czy mamy do czynienia ze współudziałem obu, podobnie jak w kwestii istnienia pierwotnej szerszej wersji Kroniki niż zachowana, z której miałby korzystać niezależnie Długosz. Dotychczasową dyskusję na temat zabytku podsumowują: S. Ekdahl, Grunwald 1410. Studia nad tradycja i źródłami, Kraków 2010, s. 142-151 (oryg. niem. 1982); M. A. Janicki, Grunwald w tradycji polskiej od XV do XVII wieku, w: Na znak świetnego zwycięstwa. W sześćsetna rocznicę bitwy pod Grunwaldem, t. 1: Studia, Kraków 2010, s. 98 n. Sceptyczny w odniesieniu do relacji o śpiewie Bogurodzicy, podobnie jak do relacji Długosza, jest Stefan Kwiatkowski (Śpiewy grunwaldzkie. Dlaczego rycerstwo Władysława Jagiełty miałoby śpiewać „Bogurodzice”” podczas kampanii w Prusach w 1410 roku?, „Przegląd Zachodniopomorski” 21, 2006, 4, s. 114-118), ze względu na propagandowy charakter Kroniki konfliktu czy odpowiednich partii Długosza. Sądzę jednak, iż nawet wobec faktu, że oba utwory miały w części propagandowe naświetlenie, nie wydaje się prawdopodobne wprowadzanie oczywistej fikcji (jaką rzekomo ma być śpiewanie Bogurodzicy) do relacji powstałej tuż po znanym wszystkim wydarzeniu, zwłaszcza że potwierdzają to inne relacje - patrz przyp. 13.

${ }^{12}$ Joannis Dlugossii Annales seu Cronicae incliti Regni Poloniae, ks. 10 i 11, red. K. Baczkowski i in., Warszawa 1997, s. 105; Jana Długosza Roczniki czyli Kroniki Sławnego Królestwa Polskiego, ks. 10 i 11, przeł. J. Mrukówna, red. S. Gawęda i in., Warszawa 1982, s. $122-123$.

${ }^{13} \mathrm{~Np}$. mowa Andrzeja Łaskarzyca wygłoszona w przed Janem XXIII w $1411 \mathrm{r}$. w Rzymie czy dzieło kaznodziejskie związane z tradycją grunwaldzką (Kodeks Mariana z Jeziorka), zob. S. Ekdahl, op. cit., s. 151 n., 285; M. A. Janicki, Grunwald, s. 103, 116. 
jeszcze w kilku innych miejscach ${ }^{14}$. Można też zauważyć, że od lat trzydziestych XV w. wzmianki o Bogurodzicy (jako pieśni i modlitwie) stają się częstsze $^{15}$. Bogurodzica pojawia się też w Statutach Łaskiego z 1506 r. (Commune incliti Polonie regni privilegium constitutionum), gdzie została przytoczona w wersji szerszej, Jan Łaski zaś jako autora podaje św. Wojciecha ${ }^{16}$. Późne wzmianki, a jednocześnie dostrzegane archaizmy (i czechizmy) językowe pieśni oraz rzekome autorstwo św. Wojciecha powodują, iż zarówno datacja, jak i okoliczności jej powstania, w tym potencjalne związki z piśmiennictwem i wpływy czeskie, budzą do dziś rozliczne kontrowersje. Ze względu na obfitość literatury wspomnijmy tylko podstawowe koncepcje odnośnie do autorstwa i inspiracji leżących u podłoża powstania tego zabytku.

W starszych badaniach silnie zaznaczył się nurt łączący pieśń - zgodnie $\mathrm{z}$ tradycją odnotowaną $\mathrm{w}$ wydaniu Statutów Łaskiego $-\mathrm{z}$ osobą św. Wojciecha ${ }^{17}$ czy też oddziaływaniem środowiska z nim związanego, choć i w tym względzie nie brakowało sceptyków ${ }^{18}$. Jednocześnie już w połowie XIX w. Wacław A. Maciejowski, wpisując się w nurt „wojciechowy", wskazywał na czechizmy i analogie do czeskiej pieśni wiązanej ze św. Wojciechem, mianowicie Hospodine pomiluj ny ${ }^{19}$. Szerzej zagadnieniem zajął się Władysław Nehring, kwestionujący zresztą autorstwo Sławnikowica. Wychodząc od polsko-czeskich związków wynikających z kierunku chrystianizacji, dostrzegał on zależność najstarszej polskiej literatury religijnej od czeskiej (oddziaływanie czeskich wzorców) również w naszym zabytku ${ }^{20}$. Wskazywał przy tym na analogie w stosunku do Hospodine po-

${ }^{14}$ Jest śpiewana przez rycerstwo jeszcze przez bitwą grunwaldzką, po wkroczeniu na ziemie nieprzyjaciela oraz w innych bitwach: pod Nakłem (1431), Wiłkomierzem (1435) (Joannis Dlugossii Annales seu Cronicae incliti Regni Poloniae, ks. 11 i 12, red. K. Baczkowski i in., Warszawa 2001, s. 42, 71, 158).

${ }^{15}$ Występuje też przy innych starciach (np. pod Warną) oraz uroczystościach państwowych w połowie XV w., zob. W. Wydra, „Es ist ein Text mit sieben Siegeln...”. O Bogurodzicy, w: idem, Dlaczego pod Grunwaldem śpiewano Bogurodzicę? Trzy rozdziały o najdawniejszych polskich pieśniach religijnych, Poznań 2000, s. 64 n.; M. A. Janicki, Bogurodzica, s. 180-182.

${ }^{16}$ Fragment Wstępu Łaskiego cytuje J. Woronczak, w: Bogurodzica, s. 121-122.

17 Stan badań od XVI w. omawia J. Birkenmajer, Zagadnienie autorstwa „Bogurodzicy”, Gniezno 1935, Studia Gnesnensia, t. 11, s. 9 nn.; W. Wydra, Dzieje, s. 195 nn. Za autorstwem św. Wojciecha: W.A. Maciejowski, Piśmiennictwo polskie, od czasów najdawniejszych aż do roku 1830, t. 1, Warszawa 1851, s. 315-321; Pieśń Bogurodzica wraz z nota z rękopisu częstochowskiego z końca wieku XV, wyd. A. Przeździecki, Warszawa 1866, s. 1; K. Konrád, Posvatná píseň polská s obzvláštním zřetelem k posvatné písni české, Praha 1885.

${ }^{18}$ Por. T. Czacki, Dzieła, wyd. E. Raczyński, t. 1, Poznań 1844, s. 66 i przyp. 264, s. 75.

19 W. A. Maciejowski, op. cit., s. 315-321.

${ }^{20}$ W. Nehring, Ueber den Einfluss der altčechischen Literatur auf die altpolnische, „Archiv für slavische Philologie" 1,1876, s. 60-81, tu s. 78. 
miluj ny (podobne zwroty modlitewne), czeskie słownictwo („slawiena”, „Zwolena”), podnosił, iż obie pełniły podobną funkcję ${ }^{21}$. Na ten kierunek poszukiwań sceptycznie zapatrywał się Aleksander Brückner, który wysunął tezę (nie podtrzymaną zresztą później) o powstaniu dzieła w drugiej połowie XIII w. w środowisku św. Kingi, żony Bolesława Wstydliwego ${ }^{22}$.Za analogiczną datacją, choć innym autorstwem (wersja łacińska - Alberyk Wielki, tłumaczenie polskie - abp Bogumił) opowiadał się Aleksander Poliński ${ }^{23}$. Z kolei Wilhelm Bruchnalski wskazywał pierwszą połowę XIV w. i zakonnika franciszkańskiego z Krakowa ${ }^{24}$. Nie brakło radykalnych koncepcji zakładających wpływy (czy pochodzenie) ruskie ${ }^{25}$; zwrócono też uwagę (A. Brückner) na możliwe inspiracje ikonograficzne, znane z Kościoła wschodniego czy ikonografii greckiej, mianowicie kompozycję trimorfion, deesis ${ }^{26}$. Czeskie oddziaływania na powstanie utworu dostrzegał też Zdeněk Nejedlý, podkreślając, iż w końcu XIV w. zdawano sobie sprawę, że pieśn to znakomity środek bojowy, sprawdzony w praktyce; sugerował więc, że na pojawienie się Bogurodzicy miał wpływ przykład najemników czeskich, śpiewających w bitwie Hospodine czy Buh všemohuci ${ }^{27}$. Na pierwsze trzydziestolecie XIII w. przesuwał ponownie utwór Teodor Wierzbowski, który przypisał dzieło Jackowi Odrowążowi ${ }^{28}$, schyłek XIII w. wskazywał zaś Jan Łoś, sugerując czas panowania Wacława II w Polsce i kulturotwórcze oddziaływanie jego dworu - nie wykluczał powstania utworu na dworze książąt śląskich czy w centrach kultury duchowej typu Kraków lub Gniez$n^{29}$. Z kolei na gruncie muzykologicznym Zdzisław Jachimecki dostrzegł analogie między początkiem Bogurodzicy a początkiem czeskiej pieśni Svatý Václave, choć nie wyciągał z tego zbyt daleko idących wniosków co do wzajemnych powiązań ${ }^{30}$.

${ }^{21}$ Ibidem, s. 78-79; idem, Studia literackie, Poznań 1884, s. 18-26.

${ }^{22}$ Koncepcję ogłosił w pracy: A. Brückner, Bogurodzica, rozwiazanie zagadki, „Biblioteka Warszawska" 4,1901; przedruk w: idem, Początki i rozwój języka polskiego. Wybór prac, red. M. Karaś, Warszawa 1974, s. 123, 127, 130, 135 n.; po czym wycofał się z niej, por. idem, Spór o „Bogurodzice”, s. 586-596, tu 587-589.

${ }^{23}$ A. Poliński, Pieśń Bogarodzica pod względem muzycznym, Warszawa 1903.

${ }^{24}$ W. Bruchnalski, O tzw. Bogurodzicy, pomniku duchownej poezji polskiej z XIV wieku, „Sprawozdania z Czynności i Posiedzeń AU” 9, 1904, nr 7, s. 3-8.

${ }^{25}$ Por. A. Brückner, Dodatki i poprawki do IV. i V. tomu „Pamiętnika Literackiego", Pam. Lit. 5, 1906, s. 310-312.

${ }^{26}$ Idem, Dzieje języka polskiego, Wrocław-Kraków 1960, s. 101.

${ }^{27}$ Z. Nejedlý, Dějiny husitského zpěvu, t. 2: Předchůdci, Praha 1954, s. 147-148.

${ }^{28}$ T. Wierzbowski, ,Bogarodzica”. Wykład wstępny w Cesarskim Uniwersytecie Warszawskim miany dnia 13 lutego r. 1909, Warszawa 1909, s. 16.

${ }^{29}$ Tak J. Łoś, Przeglad językowych zabytków staropolskich do r.1543, Kraków 1915, s. 360 n.

${ }^{30}$ Z. Jachimecki, Historia muzyki polskiej w zarysie, Warszawa 1920, s. 13-17. 
Wschodni kierunek oddziaływań widział ponownie w Bogurodzicy Julian Krzyżanowski, akcentujący językowe wpływy ruskie i przesuwający jej powstanie na przełom XIV/XV w., kiedy w państwie jagiellońskim nasilają się kontakty polsko-ruskie ${ }^{31}$. Dalszą dyskusję w latach trzydziestych XX w. znacząco ożywił Józef Birkenmajer, który akcentował silne związki zabytku z hymnologią bizantyńską, początkowo włączając autorstwo Wojciecha (uwzględniał jego włoskie pobyty i możliwy kontakt z tradycją grecką), potem sugerując środowisko z nim związane ${ }^{32}$. Z kolei Tadeusz Lehr-Spławiński dostrzegał zapożyczenia na poziomie językowym za pośrednictwem czeskim, ale wiązał je z pierwszą fazą przejmowania terminologii religijnej za Mieszka I. Nie wykluczał też późniejszych (niż powstanie pieśni) modyfikacji językowych. W kontekście czasu powstania uznał, że mogła być ona równoczesna bulli Innocentego II dla arcybiskupstwa gnieźnieńskiego z $1136 \mathrm{r}^{33}$

Zaznaczmy, że i w późniejszych badaniach nie brakło twierdzeń o wyraźnych wpływach bizantyńskich czy cerkiewnosłowiańskich. Przykładowo Roman Jakobson, wspomagając się pieśnią Hospodine, widział w Bogurodzicy trzy warstwy: starosłowiańską w wersji czeskiej („Bogorodzica”, „bogiem slawiena”, „Gospodzina”), czeską („matko zwolena”, „twego”, „spuści”, „zbożny”) i polską. Wnioskował więc, że miała u podstaw tekst staro-cerkiewno-słowiański, który w pierwszej kolejności został „sczeszczony", potem zaś spolszczony ${ }^{34}$. Kierunek ten zyskał też dalszych zwolenników ${ }^{35}$. $Z$ kolei w badaniach powojennych możliwe czeskie zależności w pieśni dostrzegał Stefan Wierczyński, wskazując na pewne analogiczne formy z czeską pieśnią Maria spomocnice ${ }^{36}$.

31 J. Krzyżanowski, Historia literatury polskiej, Warszawa 1939; por. idem, Znowu o „Bogurodzicy”, s. 14, 19; idem, Dzieje literatury polskiej, Warszawa 1979, s. 21.

32 J. Birkenmajer, Na śladach źródeł „Bogurodzicy”, „Ruch Literacki” 9, 1934, nr 1, s. 1-6, zwł. 2 n.; nr 6, s. 161-163; idem, Zagadnienie, s. 35-56, 91-95, 105 n., 109-113; idem, Glossy do „Prawdy o Bogurodzicy”, „Ruch Literacki” 12, 1937, nr 1, s. 17-20, zwł. 17, 19.

${ }_{33}$ T. Lehr-Spławiński, Uwagi o języku Bogurodzicy, w: Prace historyczno-literackie. Księga zbiorowa ku czci Ignacego Chrzanowskiego, Kraków 1936, s. 85-107, zwł. 106 n.; idem, Język polski, s. 107.

${ }^{34}$ O. Jansen [R. Jakobson], Český podíl na církevněslovanské kultuře, w: Co daly naše země Evropě a lidstvu. Od slovanských věrozvěstů k národnímu obrození, Praha 1939, s. 18; por. idem, Polska literatura średniowieczna i Czesi, „Kultura” 1953, nr 6, s. 30-31.

${ }^{35}$ M.in. B. Havránek, Otázka egzistence církevní slovanštiny v Polsku, ,Slavia” 25, 1956, z. 2, s. 304 n.; A. Stender-Petersen, Die kyrillo-methodianische Tradition bei den Polen, w: Cyrillo-Methodiana. Zur Frühgeschichte des Christentums bei den Slaven 863-1963, red. M. Hellmann i in., Köln-Graz 1964, s. 440-469.

${ }^{36}$ S. Wierczyński, Stosunki kulturalne polsko-czeskie, w: Pamiętnik VII Powszechnego Zjazdu Historyków Polskich we Wrocławiu 19-22 września 1948, t. 1, Wrocław 1948, s. 257. 
Znaczący postęp w dyskusji wniósł szereg prac publikowanych w latach pięćdziesiątych-siedemdziesiątych XX w. Wówczas to starły się trzy zasadnicze koncepcje: reprezentowana przez Jerzego Woronczaka, który łączył zabytek z połową/drugą połową XIII w. ${ }^{37}$, Ewy Ostrowskiej przesuwającej go na wiek $\mathrm{XI}^{38}$ i Stanisława Urbańczyka, wskazującego raczej wiek XIV oraz eksponującego wpływy czeskie ${ }^{39}$.

Zainteresowanie Bogurodzica nie zanikło w kolejnych dziesięcioleciach. Tradycja świętowojciechowa okazała się niezwykle żywotna, tak $\mathrm{w}$ tradycyjnym ${ }^{40}$, jak i bardziej nowatorskim ujęciu. Wedle wiążącego w całość koncepcje poprzedników Antoniego Czyża dzieło to, jako znak wspólnoty Wschodu i Zachodu, wykazujące wpływy bizantyńskie, słowiańskie czy nawet neoplatonizmu XII w., powstało w środowisku płockich benedyktynów, opactwa misyjnego Wojciecha, może w wieku XII ${ }^{41}$. Na Płock i dwór Judyty, żony Władysława Hermana, na którym mogli znajdować się mnisi sazawscy (nie wykluczając jednak udziału miejscowych benedyktynów), wskazywał też Włodzimierz Szafrański, ponownie odwołując się do wzorców czeskich (pieśni Hospodine) i datując zabytek na lata osiemdziesiąte XI w. ${ }^{42}$

W dalszych badaniach nad pieśnią zaznaczyło się jednak wyraźnie jej późniejsze datowanie.Jan Okoń podjął próbę rozpatrzenia Bogurodzicy jako czynnika kształtowania świadomości narodowej,jednego z „symboli jednoczących naród". Uwzględniając różne elementy budujące tę świadomość, w tym rolę kultów w Polsce i Europie oraz rodzaj pobożności Jagiełły, wnioskował, iż ,jeśli nie samą genezę, to [- - ] upowszechnienie się Bogurodzicy jako carmen patrium wiązać by trzeba z kultywowanym na dworze Jagiełły i jego litewsko-ruskiego otoczenia rodzajem pobożności" ${ }^{3}$. Wśród

${ }^{37}$ J. Woronczak, Wstęp filologiczny, s. 14 n.; przedruk: idem, Studia o literaturze średniowiecza i renesansu, Wrocław 1994, s. 84.

${ }^{38}$ E. Ostrowska, 0 artyźmie, s. 64 n.

${ }^{39}$ S. Urbańczyk, „Bogurodzica”, s. 113-148.

${ }^{40}$ M. Karpluk, O najwcześniejszym polskim słownictwie chrześcijańskim, w: O języku religijnym. Zagadnienia wybrane, red. eadem, J. Sambor, Lublin 1988, s. 97; por. też R. Pawłowska, „Bogurodzica”- język poetycki w epoce św. Wojciecha, w: Tysiac lat polskiego słownictwa religijnego, red. B. Kreja, Gdańsk 1999, s. 35-46. Pojawiają się też głosy opozycyjne, zob. H. Fros, Czy biskup-męczennik pozostawił po sobie spuściznę literacka??, w: Tropami Świętego Wojciecha, red. Z. Kurnatowska, Poznań 1999, s. 135, 144.

${ }^{41}$ A. Czyż, „Bogurodzica” między Wschodem a Zachodem (Kilka myśli o duchowej jedności Europy), w: Polono-slavica Varsoviensia. Prace z literatury polskiej i czeskiej na XI Międzynarodowy Kongres Slawistów w Bratysławie, red. J. Pelc, A. Nowicka-Jeżowa, Warszawa 1992, s. 25-45, zwł. s. 37.

${ }^{42}$ W. Szafrański, Wykopaliska płockie a sprawa „Bogurodzicy”, w: Słowiańszczyzna w Europie średniowiecznej, red. Z. Kurnatowska, t. 1, Wrocław 1996, s. 169-172.

${ }^{43}$ J. Okoń, Św. Wojciech i Bogurodzica jako czynniki kształtowania polskiej świadomości 
kolejnych badaczy wiek XIV jako czas powstania zabytku zdaje się najczęstszy: Stanisław Podobiński wskazywał jego drugą połowę ${ }^{44}$, Rudolf Flotzinger wiązał pieśń z zabiegami Karola IV o odnowienie liturgii słowiańskiej w Czechach i polskim oddźwiękiem tych tendencji - czyli Bogurodzica mogła powstać w Polsce południowo-wschodniej u schyłku XIV w., Czechom zaś „przypadałaby rola pośrednicząca” ${ }^{45}$. Zdaniem Josipa Hamma mogła zostać przywieziona do Krakowa wraz ze świtą Jadwigi Węgierskiej, słowa zaś uznawane dotychczas za czeskie czy staropolskie wiązałyby się z liturgią słowiańską południowej Słowiańszczyzny ${ }^{46}$. Z kolei Andrzej Dąbrówka wskazuje na konflikt polsko-krzyżacki jako czas sprzyjający powstaniu pieśni (ok. 1400), może w środowisku gnieźnieńskim, choć nie wyklucza też krakowskiego ${ }^{47}$. Pojawiła się także koncepcja przypisująca autorstwo pieśni Gertrudzie Mieszkównie, żonie Izjasława Kijowskiego ${ }^{48}$, czy tłumacząca jej powstanie pozostałościami kultu pogańskiego Matki-Ziemi ${ }^{49}$. Wciąż też podejmowane są próby weryfikacji hipotez o powiązaniach pieśni z kulturą bizantyńską ${ }^{50}$.

Mimo różnorodności dotychczasowych koncepcji najpełniej uargumentowane wydaje się stanowisko J. Woronczaka i S. Urbańczyka, zatem przyjrzyjmy się bliżej tym uzasadnieniom. Wedle Woronczaka część najstarsza Bogurodzicy stanowi trop (albo dwa tropy) do litanijnego Kyrie eleison. Wśród rymów dostrzegał podobieństwo do sekwencji francuskich, czyli schematy wersyfikacyjne poezji łacińskiej. Konstatował też, że melodia pieśni odpowiada brzmieniu litanii do wszystkich świętych Kyrie eleison, znanej z kręgu niemieckiego i zapisanej już w XI-XII w. w rękopisach zachowanych w Minden i Grazu. Uwzględniając brak nawiązań do późniejszych (od XIV w.) typów hymnografii łacińskiej, archaizmy językowe, fakturę melodii (XII-XIII w.) oraz związki utworu z ikonografią

narodowej (do początków renesansu w Polsce), „Ruch Literacki” 39, 1998, z. 6, s. 699-719, tu s. $702,704,715 \mathrm{n}$.

${ }^{44}$ S. Podobiński, Bogurodzica jako pieśń w istocie nadal nie znana?, w: „Prace Naukowe WSP w Częstochowie", Zeszyty Historyczne, z. 3, 1996, s. 138.

${ }^{45}$ R. Flotzinger, Jeszcze w kwestii „Bogurodzicy”, Pam. Lit. 96, 2005, z. 2, s. 10.

${ }^{46}$ J. Hamm, „Bogurodzica” $w$ perspektywie południowosłowiańskiej, Pam. Lit. 96, 2005, z. 2, s. 17-23.

${ }^{47}$ A.Dąbrówka, Matka pieśni polskich, Pam. Lit. 96, 2005, z. 2, s. 51-63, tu s. 57 nn.

${ }^{48}$ M. Dziwisz, Nowa hipoteza i nowe dowody w sprawie powstania i autorstwa „Bogurodzicy”, ,Forum Myśli Wolnej” 2007, nr 32-33, s. 52-59.

${ }^{49}$ J. Krzysztoforska-Doschek, Najwcześniejsze polskie teksty średniowieczne i ich więzy z tradycjami twórczości europejskiej, ,Wiener Slavistisches Jahrbuch” 54, 2008, s. 221-236, zwł. $233 \mathrm{n}$.

${ }^{50}$ H.-P. Hoelscher-Obermaier, Zur Genese der Bogurodzica, „Die Welt der Slaven” 27, 1982, z. 1, s. 90-105; A. Wilkoń, „Bogurodzica”: największa zagadka filologiczna poezji polskiej, w: idem, Arcydzieła liryki staropolskiej, Kraków 2005, s. 15-33, zwł. s. 31 n. 
romańską (motyw deesis, znany m.in. z romańskiej polichromii kolegiaty w Tumie pod Łęczycą, z paralelami do malarstwa nadreńskiego), wskazuje jako czas powstania połowę lub drugą połowę XIII w. Zdaniem badacza malowidło Deesis (czyli przedstawienie Chrystusa, z Marią i św. Janem po bokach jako orędownikami) mogło natchnąć polskiego autora tekstu: jak wiadomo bowiem, pierwsza strofa pieśni to odwołanie do Maryi, w drugiej pojawia się św. Jan Chrzciciel ${ }^{51}$. Na gruncie muzykologii datację Woronczaka poparł Hieronim Feicht, uznając, iż melodyka pieśni odpowiada dobie XII-XIII w., choć bardziej skłonny jest wiązać ją z wiekiem XIII.Jednocześnie powątpiewał w oddziaływania pieśni czeskich (tj. Svatý Václave) ${ }^{52}$.

Z kolei zdaniem jego oponenta, S. Urbańczyka, Bogurodzicę należy rozpatrywać przede wszystkim w związku z czeską kulturą literacką, wzbogaconą wpływami starosłowiańskimi i łacińskimi. Przegląd rozwoju liryki czeskiej w języku narodowym pozwolił mu wykazać ewolucyjność procesu i uznać, iż gdyby Bogurodzica była zabytkiem czeskim, należałoby ją umieścić między pieśnią Svatý Václave (którą datuje na połowę XII w.) a Pieśnia Ostrowska (XIII w.), kultura zaś polska była bardziej zapóźniona (o wiek). Analizując słownictwo polskiej pieśni, skłania się do wniosku, iż wiązała się z rozkwitem łacińskiej twórczości sekwencyjnej w Polsce XIV w. i ożywionymi kontaktami polsko-czeskimi czasów Wacławów i Luksemburgów ${ }^{53}$. Podkreślał, iż Bogurodzica odgrywała podobną rolę kultowo-polityczną jak Hospodine pomiluj ny, wskazując równocześnie na jej liczne czechizmy ${ }^{54}$. W efekcie konstatuje, że autor Bogurodzicy znał twórczość czeską, co więcej, rola Hospodine pomiluj ny, niejako hymnu państwowego za ostatnich Przemyślidów i Luksemburgów, zainspirowała go do stworzenia najstarszej polskiej pieśni ${ }^{55}$.

${ }^{51} \mathrm{~J}$. Woronczak, Tropy, s. 350-353; idem, Wstęp filologiczny, s. 11-15; przedruk w: idem, Studia o literaturze średniowiecza i renesansu, s. 80-84.

${ }^{52}$ H. Feicht, Wstęp muzykologiczny, w: Bogurodzica, s. 51-81, tu s. 58 n., 71, 78 n. Dodajmy jednak, iż w najnowszych badaniach pojawiła się krytyka tez J. Woronczaka odnośnie do traktowania Bogurodzicy jako tropu kyrialnego, por. R. Flotzinger, op. cit., s. 7-10, tu s. 8; zakwestionowano jej określone niemieckie wzorce czy chronologię, por. J. Pikulik, Co melodia „Bogurodzicy” mówi nam o czasie powstania pieśni, Pam. Lit. 96, 2005, z. 2, s. 13-15.

${ }^{53}$ S. Urbańczyk, „Bogurodzica”, s. 113-148, zwł.127,147 n.

${ }^{54}$ Ibidem, s. 143.

55 Ibidem, s. 143, 145. Odnotujmy, że recenzujący ustalenia Urbańczyka Gerard Labuda, nie rezygnując z tropu czeskiego, zauważa, że w tym okresie „stosunki polityczne nie są dobrym tłem dla współpracy kulturalnej polsko-czeskiej”. Jednocześnie akcentuje innego adresata obu pieśni, tzn. na polską wpływ miał kult maryjny, którego rozkwit wiąże z rozwojem zakonów dominikańskiego i franciszkańskiego, dlatego jako pośredników wskazuje raczej te zakony, połączone wspólną prowincją, zob. G. Labuda, 


\section{Gdzie i kiedy mogła powstać Bogurodzica?}

Najpierw przypomnijmy dostrzegane tekstowe wpływy czeskie w dwóch pierwszych zwrotkach, leżące u podstaw argumentacji części badaczy. Zwracano uwage na tytuł utworu, nie jest to bowiem słowo pochodzenia rodzimego i nader rzadko pojawia się w kanonie średniowiecznego piśmiennictwa (tylko w Modlitwach Wacława z XV w.). Łączy się go ze staro-cerkiewno-słowiańskim: bogorodzica (z grec. Theotokos). Jako że koncepcja wpływów ruskich w zasadzie nie utrzymała się w badaniach, nie sposób również znaleźć dowodów na obecność liturgii słowiańskiej w Polsce południowej ${ }^{56}$, pozostaje ślad czeski, w związku z obecnym na tym terenie piśmiennictwem słowiańskim ${ }^{57}$. Jest to więc albo - jak chciał np. T. Lehr-Spławiński - słowo należące do najwcześniejszych zapożyczeń terminologii religijno-kościelnej (o genezie starosłowiańskiej) za pośrednictwem języka czeskiego ${ }^{58}$, albo nowsza, bliższa czasowi powstania pożyczka czeska (S. Urbańczyk). Druga wersja wydaje się bardziej zasadna, uwzględniając chociażby analogiczną zmianę form boho- w bohu- (bogu-) w Polsce i Czechach ${ }^{59}$. Z dalszych możliwych czechizmów wskazuje się słowa: „sławiena”, „zwolena” (z e zamiast o), które T. Lehr-Spławiński łączy bądź z pierwszą falą wpływów, bądź z późniejszymi niż powstanie pieśni wpływami czeskimi (przełom XIV/XV w.) ${ }^{60}$. Dyskusję budzą zwroty: „napełń myśli”, „zbożny pobyt” uznawane bądź za czechizmy, bądź wyrazy rodzime ${ }^{61}$. Zdaniem S. Urbańczyka, które akceptuje zresztą wielu slawistów i które wydaje się uzasadnione: „niektóre z nich mają lepszą dokumentację w języku czeskim (napełnić myśli, przebyt, pobyt, zwolić), a przebyt i zwolić wolno uważać za pożyczki bądź wyrazowe (przebyt), bądź

rec.: Stanisław Urbańczyk, „Bogurodzica”. Problemy czasu powstania i tła kulturalnego, „Pamiętnik Literacki” 69 (1978), St. Źr. 29, 1985, s. 229 n.

56 Por. m.in. G. Labuda, Studia nad poczatkami państwa polskiego, t. 2, Poznań 1988, s. 151-166; K. Polek, Poczatki chrześcijaństwa na terenach na południe od Karpat i w Małopolsce, w: Święty Świerad i jego czasy. Materiały z sympozjum naukowego w Tropiu 10-11 lipca 1998, red. ks. S. Pietrzak, Nowy Sącz 2001, s. 122-128; J. Dobosz, Monarcha i możni wobec Kościoła w Polsce do poczatku XIII wieku, Poznań 2002, s. 17-24.

${ }^{57}$ Por. Z. Huptová, Církevněslovanské písemnictví v přemyslovských Čechách, w: Jazyk a literatura $v$ historické perspektivě, red. D. Moldanová, Ústí nad Labem 1998, s. 5-41; R. Večerka, Staroslověnská etapa českého písemnictví, Praha 2010.

${ }^{58}$ T. Lehr-Spławiński, Uwagi, s. 88 n.; idem, Jezzyk polski, s. 108; akceptuje T. Ostrowska, Wstęp i komentarz językowy, w: Bogurodzica, s. 27; eadem, 0 artyźmie, s. 17.

${ }^{59}$ S. Urbańczyk, „Bogurodzica”, s. 130.

${ }^{60}$ T. Lehr-Spławiński, Uwagi, s. 90 n.; por. por. jednak T. Ostrowska, Wstęp, s. 29; eadem, 0 artyźmie, s. 19.

${ }^{61}$ Przegląd starszej dyskusji podaje T. Lehr-Spławiński (Uwagi, s. 102-104), sam opowiadając się za ich rodzimym pochodzeniem. 
znaczeniowe (zwolić)”62. Również słowo „bożyc”, nie potwierdzone w języku polskim, znajduje potwierdzenie w piśmiennictwie czeskim XIV $\mathrm{w}^{63}$

Niewątpliwie kwestia zapożyczeń słownictwa religijnego z obszaru czeskiego i chronologia tego zjawiska stanowi równie kontrowersyjny problem w badaniach nad średniowiecznymi dziejami języka i kultury polskiej. Wahania w tym względzie są znaczne: od badaczy wskazujących znaczny udział tych zapożyczeń (Edward Klich) do marginalizacji zjawis$\mathrm{ka}^{64}$. Rozwiązania zadowalającego oba obozy z pewnością nie osiągniemy, zgodzić się bowiem trzeba z pojawiającym się już stwierdzeniem, że zbyt mała liczba zabytków nie pozwoli nam precyzyjnie określić czasu przepływu terminologii czeskiej do Polski. Warto jednak w tym kontekście podnieść jeden aspekt. Jeśli przyjmiemy potencjalne oddziaływania czeskie w tym zakresie, to w pierwszej kolejności byłyby najprawdopodobniej zapożyczane terminy potrzebne do funkcjonowania budującego się Kościoła polskiego i pogłębiania chrystianizacji. Wydają się więc oczywistymi i niezbędnymi zapożyczeniami terminy przytaczane przez E. Klicha: „apostoł, bierzmowanie, biskup, arcybiskup, chrzcić, chrzest, chrześcijanin, cmentarz, diabeł, dziekan, jałmużna, kacerz, kapła z kaplicą, kapłan, kielich, klasztor, kmotr, kolęda, kościół, kruchta, krzyż, lucyper, małżonka, mnich, msza, nieszpor, ofiara, ofiarować, ołtarz, opat, opłatek, pacierz, papież, parochia, pleban, poganin, pop, post, prałat, przeor, sobota, szatan, wigilia, żak, żałm, żegnać, żyd"65. Jednak wskazywane potencjalnie czeskie słownictwo Bogurodzicy zdaje się reprezentować inny, wyższy typ, mianowicie związany z pogłębioną religijnością i rozwojem piśmiennictwa oraz twórczości literackiej. Zestawmy słownictwo podejrzane o pochodzenie czeskie (pogrubienia) i przypomnijmy też podkreślane przez W. Nehringa zbieżności tekstowe (podkreślenia) między Bogurodzica a Hospodine ${ }^{66}$ :

${ }^{62}$ S. Urbańczyk, „Bogurodzica”, s. 143; por. T.Z. Orłoś, Polsko-czeskie związki językowe, Wrocław-Warszawa-Kraków 1980, s. 12; por. udostępnioną w formie online dokumentację obejmującą słowniki staroczeskie i materiały do nich: Vokabulář webový [on-line]. Verze 0.4.2. Oddělení vývoje jazyka Ústavu pro jazyk český AV ČR, v. v. i. 〈http:// vokabular.ujc.cas.cz> (dostęp: 5 V 2013) [według haseł].

${ }^{63}$ S. Urbańczyk, „Bogurodzica”, s. 138 n., 142 n.; patrz wyżej.

${ }^{64}$ Por. D. Sikorski, O czeskiej proweniencji polskiej terminologii kościelnej, w: Przemyślidzi i Piastowie - twórcy i gospodarze średniowiecznych monarchii, red. J. Dobosz, Poznań 2006, s. 101-106; idem, Początki Kościoła w Polsce. Wybrane problemy, Poznań 2012, s. 223-272 (tu dyskusja i dalsza liter.).

${ }^{65}$ Tak E. Klich, Polska terminologia chrześcijańska, Poznań 1927, s. 147, do czego dodaje z pewnym wahaniem: „anioł, archanioł, ewangelia, [ewangelista?], ksiądź, proboszcz, żałtarz/żołtarz" itd.

${ }^{66}$ W. Nehring, Ueber den Einfluss, s. 79; idem, Studia, s. 23. 
Bogurodzica

Hospodine pomiluj ny

Bogurodzica dziewica, Bogiem sławiena

Maryja,

U twego syna Gospodzina matko zwolena,

Hospodine, pomiluj ny!

Maryja!

Zyszczy nam, spu〈ś $\rangle$ ci nam.

Jezukriste, pomiluj ny!

Kyrieeleison.

Twego dziela Krzciciela, bożycze,

Ty spase všeho mira

Spasiž ny i uslyšiž,

Usłysz głosy, napełń myśli człowiecze.

Hospodine, hlasy naše!

Słysz modlitwę, jąż nosimy,

A dać raczy, jegoż prosimy:

Daj nam všem, hospodine,

žiz a mír v zemi

A na świecie zbożny pobyt,

Krleš, krleš, krleš!

Po żywocie ra〈j〉ski przebyt.

Kyrieeleison ${ }^{67}$

Jako laikowi trudno mi rozstrzygać problemy, nad którymi pochylało się już tylu wybitnych językoznawców i literaturoznawców ${ }^{68}$. Zauważmy jednak, iż jak na dość krótki utwór, jakim jest Bogurodzica, liczba analogii musi budzić zastanowienie. Interesujące jest też inne spostrzeżenie Nehringa, mianowicie że rymy Bogurodzicy, gdyby je przekształcić na czeskie, "są czystsze aniżeli polskie" 69 .

W tej sytuacji tezy, iż autor znał literaturę staroczeską, a więc prawdopodobnie również najstarsze pieśni (W. Nehring, S. Urbańczyk), nie należy pochopnie odrzucać. Przypomnijmy dodatkowo, iż muzykolodzy dostrzegali też pewne podobieństwo muzyczne początkowej frazy Bogurodzicy do początku pieśni Svatý Václave ${ }^{70}$, choć sceptyczny Feicht kwestionował ich związki, uznając, że są bardziej dosłownie pokrywające się wzorce, jakkolwiek „ogólny nastrój, jaki wywołują obie melodie, jest oczywiście podobny"71. Można się jednak zastanowić, czy np. znajomość pieśni czeskich nie posłużyła jako punkt wyjścia do poszukiwań owych doskonalszych wzorców. Wobec wyraźnego osamotnienia Bogurodzicy w piśmiennictwie polskim trudno nam wspomagać się innymi zabytka-

${ }^{67}$ BJ, rkp. sygn. 1619, transkrypcja za: Bogurodzica, s. 96.

${ }^{68}$ Niektórzy badacze konstatowali brak możliwości rozstrzygnięcia, czy w owych formach powinniśmy mówić o archaizmach czy czeskich pożyczkach, por. J. Woronczak, Tropy, s. 352.

${ }^{69}$ W. Nehring, Studia, s. 23.

${ }^{70}$ Z. Jachimecki, op. cit., $16 \mathrm{n}$.

${ }^{71}$ H. Feicht, op. cit., s. 58 n. 
mi dla oceny prawdopodobieństwa znajomości w Polsce piśmiennictwa czy pieśni czeskich przed XIV w. Jednak w odniesieniu chociażby do piśmiennictwa łacińskiego obu krajów możemy dostrzec ślady wzajemnych kontaktów - przede wszystkim w rocznikarstwie polskim, zarówno tym XIII w., jak i najstarszym, można zaobserwować oddziaływanie dziejopisarstwa czeskiego ${ }^{72}$. Skoro zaś wśród polskiego duchowieństwa mogli być ludzie znający czeską twórczość dziejopisarską, zasadne wydaje się przyjęcie, że tym bardziej mogli znać twórczość religijną. Jak wykazał już Antoni Barciak, kontakty polskiego i czeskiego duchowieństwa w wieku XIII i XIV były bardzo częste ${ }^{73}$.

Już w tym momencie warto zwrócić uwagę na dwie dalsze kwestie. Dla badaczy problemu nie ulega wątpliwości, że Bogurodzica to utwór skomplikowany, przeznaczony pierwotnie do śpiewu przez wyszkolony chór. Jeśli zaś, jak donoszą źródła, pieśń śpiewało rycerstwo pod Grunwaldem, można wnioskować, że w tym czasie nie był to utwór nowy, a społeczeństwo musiało przez długi czas oswajać się z nim, uczestniczyć najpierw zapewne biernie, później zaś czynnie w jego śpiewaniu podczas mszy lub innych uroczystości ${ }^{74}$. Skoro Długosz określa ją jako carmen patrium, ta jej funkcja nie zaistniała raczej niespodziewanie dopiero w trakcie bitwy pod Grunwaldem. Związanie się Bogurodzicy z uroczystościami o charakterze nie tylko religijnym, ale i państwowym musiało chyba nastąpić wcześniej. Przypomnijmy też, że już u schyłku XV w. staje się ona pieśnią ludową, „dziadowską"75. Ta ewolucja i jej chronologia sugeruje, że genezy pieśni

${ }^{72}$ T. Jasiński, Rocznik poznański. Ze studiów nad annalistyka polską i czeska, w: Aetas media, aetas moderna. Studia ofiarowane profesorowi Henrykowi Samsonowiczowi w siedemdziesiąta rocznicę urodzin, red. H. Manikowska, A. Bartoszewicz, W. Fałkowski, Warszawa 2000, s. 664-672, zwł. 671 n.; idem, Początki polskiej annalistyki, w: Nihil superfluum esse. Studia z dziejów średniowiecza ofiarowane Profesor Jadwidze Krzyżaniakowej, red. J. Strzelczyk, J. Dobosz, Poznań 2000, s. 129-146; M. Matla-Kozłowska, Qui a quo - wzajemne wpływy polskiego i czeskiego rocznikarstwa we wczesnym średniowieczu (X-XI w.), w: Causa creandi. 0 pragmatyce źródła historycznego, red. S. Rosik, P. Wiszewski, Wrocław 2005, s. 67-89; eadem, Kwestia zależności polskiego i czeskiego rocznikarstwa od drugiej połowy XI w. do połowy XIII w., St. Źr. 43, 2005, s. 27-52.

${ }^{73}$ A. Barciak, Czechy a ziemie Polski południowej w XIII oraz na początkach XIV wieku, Katowice 1992, s. 12 nn.

${ }^{74}$ Może też w czasie Bożego Narodzenia, jak przypuszczają Roman Mazurkiewicz i Zofia Wanicowa, Dlaczego „Bogurodzicę” śpiewano w liturgicznym okresie Bożego Narodzenia?, Pam. Lit. 96, 2005, z. 2, s. 25-41.

75 O dalszych losach Bogurodzicy zob. B. Walczak, Dzieje najstarszej polskiej pieśni, „Życie i Myśl” 33, 1984, nr 6, s. 47-63, zwł. 50 nn.; W. Wydra, Es ist, s. 64 nn.; T. Michałowska, Leksykon, s. 137; o zaniku jej popularności por. też K. Meller, Carmen patrium: Bogurodzica?, w: eadem, „Noc przeszła, a dzień się przybliżył”. Studia o polskim piśmiennictwie reformacyjnym XVI wieku, Poznań 2004, s. 15-19. 
należałby szukać znacznie wcześniej, tj. przynajmniej stulecie wcześniej niż bitwa grunwaldzka.

S. Urbańczyk, umiejscawiając Bogurodzicę w rozwoju polskiej twórczości literackiej, zwracał uwagę na ważną kwestię, mianowicie brak języka polskiego w piśmiennictwie i, co więcej, w Kościele, co jego zdaniem nie sprzyjało pojawieniu się utworu przed XIV w. Okoliczności te wydają się warte rozważenia. Zastanówmy się więc, kiedy w Kościele polskim, w szerszym kontekście społecznym, zaistniały sprzyjające warunki do pojawienia się nie tylko religijnego, ale może i patriotycznego utworu w języku polskim, jakim była czy też stała się Bogurodzica. Uwzględnienie późniejszej funkcji pieśni wydaje się bowiem mieć znaczenie dla ustalenia okoliczności jej powstania.

Sądzę, że w celu wyjaśnienia genezy Bogurodzicy należy zwrócić uwagę na sytuację drugiej połowy XIII w. w Polsce i konflikty narodowościowe, które skłoniły polską hierarchię kościelną do zaangażowania się w propagowanie języka polskiego w Kościele. Na przełom XIII/XIV w. datują badacze wyraźny wzrost poczucia świadomości narodowej w społeczeństwie polskim, przy czym czynnikiem jednoczącym i pobudzającym były m.in. antyniemieckie nastroje części społeczeństwa czy raczej jego elit. Nie wchodząc w szczegółową analizę kwestii rodzenia się świadomości narodowej ${ }^{76}$, przypomnijmy, w ogólnym zarysie, problemy Kościoła i społeczeństwa polskiego w drugiej połowie XIII w.

${ }^{76} \mathrm{Z}$ podstawowych, powojennych prac na ten temat zob. m.in. R. Grodecki, Powstanie polskiej świadomości narodowej, Katowice 1946; M. Friedberg, Kultura polska a niemiecka. Elementy rodzime a wpływy niemieckie w ustroju i kulturze Polski średniowiecznej, t. 2, Poznań 1946, zwł. s. 118-128; J. Baszkiewicz, Powstanie zjednoczonego państwa polskiego na przełomie XIII i XIV wieku, Warszawa 1954, passim; R. Heck, Uwagi o rozwoju polskiej i czeskiej świadomości narodowej w średniowieczu, w: Studia nad rozwojem narodowym Polaków, Czechów i Słowaków, red. idem, Wrocław 1976, s. 5-24; B. Zientara, Konflikty narodowościowe na pograniczu niemiecko-słowiańskim w XII-XIV w. i ich zasięg społeczny, PH 59, 1968, 2, s. 197-213; idem, Cudzoziemcy w Polsce X-XV wieku: ich rola w zwierciadle polskiej opinii średniowiecznej, w: Swojskość i cudzoziemszczyzna w dziejach kultury polskiej, red. Z. Stefanowska, Warszawa 1973, s. 9-37; F. Graus, Die Nationenbildung der Westslawen im Mittelalter, Sigmaringen 1980; S. Gawlas, Społeczny zasięg świadomości narodowej w późnym średniowieczu. Analiza mechanizmów zjawiska, PH 72, 1981, 4, s. 637-662; A. Barciak, Problemy świadomości narodowej w stosunkach czesko-polskich $w$ średniowieczu, w: Czechy i Polska na szlakach ich kulturalnego rozwoju, red. J. Grell, Kraków 1998, s. 43-52; H. Samsonowicz, „My Polacy”, czyli o początkach polskiej świadomości narodowej, w: Historia vero testis temporum, red. J. Smołucha i in., Kraków 2008, s. 617-628. Obszerne omówienie dotychczasowej historiografii w tym zakresie daje Sławomir Gawlas, Stan badań nad polska świadomościa narodowa w średniowieczu, w: Państwo, naród, stany w świadomości wieków średnich. Pamięci Benedykta Zientary 1929-1983, red. A. Gieysztor, S. Gawlas, Warszawa 1990, s. 149-194. 
Wiek XIII to okres intensywnej kolonizacji, a zatem napływu ludności niemieckiej na ziemie polskie: chłopów, mieszczaństwa, ale i rycerstwa szukającego kariery na dworach piastowskich książąt ${ }^{77}$. Już na szczeblu najniższym kontakty między polską hierarchią kościelną a osadnikami przybierały postać sporów - w zakresie obyczajowości (kwestia postów), odmawiania płacenia dziesięcin według „polskiego obyczaju” czy opłaty świętopietrza - rozwiązywanych przez legatów papieskich ${ }^{78}$.Jednocześnie też zaznaczył się intensywniejszy napływ duchowieństwa niemieckiego, które zaczęło dominować liczebnie w klasztorach, obejmowało probostwa, funkcje w kapitułach czy na dworach. Powstawały nowe parafie na potrzeby niemieckich osadników, przy których prawdopodobnie tworzyły się niemieckojęzyczne szkoły ${ }^{79}$. Jednak spór w Kościele na tle narodowościowym zainicjowały w zasadzie zakony, zwłaszcza franciszkanie na Śląsku, gdzie dominowali bracia pochodzenia niemieckiego ${ }^{80}$. Antypolska postawa franciszkanów śląskich przejawiała się poprzez ograniczanie Polakom wstępu do klasztorów czy wprowadzanie zakazów wybierania ich na urzędy zakonne ${ }^{81}$, w dalszej kolejność na Śląsku doszło do ich uniezależniania się od miejscowej hierarchii kościelnej. Konflikt nasilił się podczas sporu między biskupem Tomaszem II a księciem wrocławskim Henrykiem IV. Mimo obłożenia księcia klątwą i nałożenia interdyktu na księstwo tylko duchowieństwo polskie respektowało w zdecydowanej większości decyzje

${ }^{77}$ Por. B. Zientara, Cudzoziemcy, s. 17 nn.; idem, Wiek XIII - wielkie przemiany, obce wpływy i świadomość narodowa, w: Uniwersalizm i swoistość kultury polskiej, red. J. Kłoczowski, t. 1, Lublin 1989, s. 61 nn., 71 n.

${ }^{78}$ B. Kumor, Kościół w obronie polskości. Działalność metropolity Jakuba Świnki, w: Historia Kościoła w Polsce, t. 1, cz. 1, red. idem, Z. Obertyński, Poznań-Warszawa 1974, s. 131-133; B. Zientara, Wiek XIII, s. 72 n.

${ }^{79}$ B. Nowacki, Arcybiskup Jakub Świnka - budziciel i propagator polskiej świadomości narodowej, w: 1000 lat archidiecezji gnieźnieńskiej, red. J. Strzelczyk, J. Górny, Gniezno 2000, s. 116.

${ }^{80}$ T. Silnicki, Dzieje i ustrój kościoła katolickiego na Ślasku do końca XIV wieku, Warszawa 1953, s. 392 nn.; C.C. Baran, Sprawy narodowościowe u franciszkanów śląskich, Warszawa 1954, s. 43-76, zwł. 65; zob. też D. Karczewski, Konflikty narodowościowe w czesko-polskiej prowincji franciszkanów do początku XVI wieku, w: Wspólnoty duże i małe w społeczeństwach Czech i Polski w średniowieczu i czasach nowożytnych, red. W. Iwańczak, J. Smołucha, Kraków 2010, s. 143.

${ }^{81}$ Dominację Niemców w prowincji polsko-czeskiej jako zagrożenie dostrzegano na dworze czeskim, jak wskazują zachowane w formularzu listy czeskiej królowej Kunegundy do ksieni trzebnickiej, córki Henryka II, czy kardynała rzymskiego, w których m.in. skarży się ona na wspomniane ograniczenia dla braci polskich i czeskich oraz oręduje w obronie języków (i zakonników) słowiańskich, zob. F. Palacký, Ueber Formelbücher, zunächst in Bezug auf böhmische Geschichte, Prag 1842, nr 54 i 55, s. 287-288; Regesta diplomatica nec non epistolaria Bohemiae et Moraviae, t. 2, wyd. J. Emler, Pragae 1882, nr 2504, 2505, s. 1077-1078; por. K. Kantak, Franciszkanie polscy, t. 1, Kraków 1937, s. 39 n.; R. Grodecki, op. cit., s. 22; A. Barciak, Czechy, s. 140 i przyp. 114, 141. 
biskupa, duchowieństwo niemieckie zaś (w tym m.in. franciszkanie) czynnie wspierało księcia, odprawiając msze w obłożonym interdyktem księstwie, książę natomiast pod groźbą surowych kar nakazał ludności korzystanie z kościołów będących w opozycji do biskupa (tj. z duchowieństwem niemieckim). Na kolejnym etapie, wobec zaognienia sporu, książę pozbawiał stanowisk duchownych polskich i likwidował klasztory, powierzając opuszczone stanowiska duchownym i mnichom niemieckim ${ }^{82}$. Kolejnym policzkiem dla Kościoła i hierarchii polskiej był wspomniany fakt oderwania ośmiu franciszkańskich klasztorów śląskich od prowincji czesko-polskiej i przyłączenia do saskiej ${ }^{83}$. Co istotne, przyczyną owych działań były właśnie konflikty narodowościowe słowiańsko-niemieckie, szczególnie silne m.in. na Śląsku ${ }^{84}$. Wreszcie nie bez znaczenia był zapewne fakt kaznodziejskiej działalności zakonu franciszkańskiego, który musiał w tej sytuacji wywoływać określone skutki, tj. propagowanie języka niemieckiego ${ }^{85}$. Dla przedstawicieli polskiej hierarchii kościelnej był to wyraźny sygnał wskazujący na potrzebę szybkiego przeciwdziałania, zwłaszcza że już w poprzedzającym okresie Kościół polski doznał strat związanych z szeroko rozumianym zagrożeniem niemieckim (strata diecezji chełmińskiej, niekorzystne zmiany związane z biskupstwem lubuskim, spory o archidiakonat słupski ${ }^{86}$. Problemy te mogły być, i zapewne były, postrzegane na tle narodowościowym i politycznym: problemu integralności państwa i Kościoła oraz groźby wynarodowienia ludności polskiej.

Wobec powyższego w styczniu roku 1285 synod prowincjonalny w Łęczycy pod przewodnictwem abp. Jakuba Świnki uchwalił statuty, które m.in. miały przeciwdziałać negatywnym skutkom obecności i poczynań niemieckiego duchowieństwa w Polsce. Statuty te reagowały na

${ }^{82}$ T. Silnicki, Rola dziejowa Kościoła polskiego na Ślasku w wiekach XI-XIII, Katowice 1935, s. 30 nn.; R. Grodecki, op. cit., s. 22 nn.; W. Karasiewicz, Jakób II Świnka, arcybiskup gnieźnieński 1283-1314, Poznań 1948, s. 251 nn.; T. Silnicki, K. Gołąb, Arcybiskup Jakub Świnka i jego epoka, Warszawa 1956, s. 159 nn.; H. Wajs, Zmiana przynależności prowincjalnej kustodii wrocławskiej i złotoryjskiej franciszkanów w drugiej połowie XIII wieku, PH 74, 1983, 2, s. 265; B. Nowacki, op. cit., s. 117.

${ }^{83}$ Problem omawiają m.in. H. Wajs, op. cit., s. 255-269; D. Karczewski, op. cit., s. 143 nn.; idem, Franciszkanie w monarchii Piastów i Jagiellonów w średniowieczu. Powstanie - rozwój - organizacja wewnętrzna, Kraków 2012, s. 58 nn., 223 nn. Hubert Wajs zaznacza tu jednak, iż inaczej to zjawisko mogła postrzegać, wobec nieznajomości form organizacji zakonu, polska hierarchia kościelna, idem, op. cit., s. 265.

${ }^{84}$ K. Kantak, op. cit., t. 1, s. 36-37; C.C. Baran, op. cit., s. 87 nn.; D. Karczewski, Konflikty, s. 144 n.; idem, Franciszkanie, s. 59.

${ }^{85}$ B. Nowacki, op. cit., s. 117.

${ }^{86}$ W. Karasiewicz, op. cit., s. 305 n.; B. Kumor, op. cit., s. 133; B. Nowacki, op. cit., s. 113. 
zaistniałą sytuację wieloaspektowo ${ }^{87}$, nas jednak w tym momencie interesować będą postanowienia związane z ochroną „rodu Polaków” (gens Polonica) i propagowaniem języka polskiego. Pojawił się m.in. przepis, aby księża w niedzielę zamiast kazania wyjaśniali wiernym po polsku Skład Apostolski, Modlitwę Pańską i Pozdrowienie Anielskie, a ci, którzy potrafią dobrze mówić po polsku, tłumaczyli ewangelie ${ }^{88}$. Konieczność propagowania języka polskiego była z większą siłą wdrażana w kolejnych statutach. W zakresie szkolnictwa: „Stautimus insuper ad conservacionem et promocionem lingwe Polonice, in singulis locis ecclesiarum kathedralium et conuentualium, et aliis quibuscunque locis non ponantur rectores scolarium, nisi linguam polonicam proprie sciant, et possint pueris auctores exponere in Polonica lingua" 89 . W dalszych postanowieniach m.in. wzywano ludność polską do bojkotu mszy w kościołach i klasztorach samowolnie zakładanych przez Niemców czy wprowadzono zakaz nadawania beneficjów związanych z posługą parafialną osobom, które nie są urodzone w Polsce i nie znają biegle języka polskiego ${ }^{90}$. Część uchwał wysłano jako suplikę do Rzymu (do kilku kardynałów), skarżąc się przy tym na poczynania zakonników niemieckich (którzy weszli do Polski, usuwają braci polskich z konwentów i próbują uczynić z Polski Saksonię), ale też obrazując niebezpieczeństwa związane tak z agresją niemieckich książąt na pograniczne ziemie polskie, jak z zachowaniem niemieckich przybyszów w Polsce (nie tylko duchownych, ale i rycerzy, chłopów), którzy opanowując polskie miasta i wsie, ograbiają Polaków z ich dóbr, gardzą narodem polskim, uciskają go i pozbawiają ojczystych praw i zwyczajów ${ }^{91}$.

Ta kontrofensywa Kościoła polskiego wiązać się mogła w części $z$ troską o dostęp duchownych Polaków do godności i beneficjów ${ }^{92}$, jak też z obawą o całość podległych im ziem, nie można jednak jej odmówić głębszego wymiaru, mianowicie dostrzeżenia ryzyka wynarodowienia

87 Omówienie: W. Karasiewicz, op. cit., s. 255 nn., 269; R. Grodecki, op. cit., s. 27 n.; T. Silnicki, K. Gołąb, op. cit., s. 112 nn.; I. Subera, Synody prowincjonalne arcybiskupów gnieźnieńskich, Warszawa 1971, s. 57-63; dalsza literatura zob. P. Krafl, Přehled provincionálních synod Hnězdna z let 1206-1503, „Slovanské historické studie” 25, 1999, s. 17.

${ }^{88}$ SPPP, wyd. A. Helcel, t. 1, Warszawa 1856, s. 383; KDW, t. 1, nr 551, s. 510 n.

${ }^{89}$ SPPP, t. 1, s. 384; KDW, t. 1, nr 551, s. 511; „Postanowiliśmy dla zachowania i dla poparcia języka polskiego, by w poszczególnych szkołach katedralnych i klasztornych byli wyznaczani tylko tacy magistrzy, którzy doskonale znają język polski, by mogli chłopcom objaśniać autorów (łacińskich) w polskim języku", tłum. za R. Grodecki, op. cit., s. 27.

${ }^{90}$ SPPP, t. 1, s. 387; I. Subera, op. cit., s. 61.

${ }^{91} \mathrm{KDW}$, t. 1, nr 616, s. 574-575; por. R. Grodecki, op. cit., s. 26; W. Karasiewicz, op. cit., s. 256; B. Zientara, Cudzoziemcy, s. 27 n.; idem, Wiek XIII, s. 73 n.; I. Subera, op. cit., s. 62 .

${ }^{92}$ R. Heck, op. cit., s. 11. 
i perspektywicznego spojrzenia na społeczeństwo i naród ${ }^{93}$.Zauważono zresztą, że tendencje antyniemieckie pojawiają się również w piśmiennictwie tego okresu, nastroje te będą się nasilać w początkach XIV w. ${ }^{94}$ Nie jest to specyfika jedynie polska, świadomość narodowa, także odwołująca się częściowo do konfliktów etnicznych i nastrojów antyniemieckich, rodzi się w drugiej połowie XIII w. w sąsiednim państwie czeskim ${ }^{95}$. Co również warte uwagi, ideologią antyniemiecką (tj. zagrożenia niemieckiego dla krajów słowiańskich) szermowano (w określonym kontekście politycznym) w relacjach polsko-czeskich - próbował ją np. wykorzystać Przemysł Ottokar II, dążąc do pozyskania książąt polskich ${ }^{96}$.

Istotne jest, że troska o przyszłość Kościoła polskiego przejawiała się zaleceniem używania języka polskiego w trakcie mszy (wyjaśnianie wiernym po polsku podstawowych modlitw czy ewangelii), suplika zaś wyraża wyraźną obawę o los narodu i całość polskiej prowincji kościelnej. Podkreślmy, iż dotychczasowe badania nad formowaniem się świa-

${ }^{93}$ Por. B. Zientara, Wiek XIII, s. 73.

${ }^{94}$ Idem, Cudzoziemcy, s. 28 n.

${ }^{95} \mathrm{O}$ rodzeniu się świadomości narodowej w Czechach zob. m.in. F. Graus, Die Bildung eines Nationalbewusstseins im mittelalterlichen Böhmen, „Historica” 13, 1966, s. 5-49; idem, Die Nationenbildung, passim; R. Heck, op. cit., passim; S. Bylina, Idee uniwersalne a czeska świadomość narodowa $w$ późnym średniowieczu, w: Państwo, naród, s. 77-99; A. Barciak, Problemy, passim; M. Bláhová, Národ v pojetí českých středověkých intelektuálů, w: Wspólnoty duże, s. 15-33 (tam dalsza literatura).

${ }^{96}$ Mowa tu o słynnym, i dyskusyjnym zresztą co do autentyczności, manifeście Przemysła II ze zbioru jego notariusza Henryka z Isernii; wydanie: Przyczynki źródłowe do ostatnich lat panowania Ottokara II, wyd. B. Ulanowski, w: SRP, t. 12, Kraków 1888, nr 9, s. 11-13; na ten temat zob. m.in. B. Włodarski, Polska i Czechy w drugiej połowie XIII i początkach XIV wieku (1250-1306), Lwów 1931, s. 81-85; M. Pośpiech, Problem autentyczności manifestu Przemysła Ottokara II do książąt polskich, SH 15, 1972, 4, s. 537-549; A. Barciak, W sprawie polityki Przemysta Ottokara II wobec Polski, PH 65, 1974, 3, s. 545-550; idem, Ideologia polityczna monarchii Przemysła Ottokara II. Studium z dziejów czeskiej polityki zagranicznej w drugiej połowie XIII wieku, Katowice 1982, s. 89 n., 104; V. Vaníček, Velké dějiny zemí Koruny České, t. 3, Praha-Litomyšl 2002, s. 189 n. Manifest powstał prawdopodobnie w środowisku królowej Kunegundy, wokół której skupiało się grono reprezentujące tendencje narodowe (taką rolę przypisuje się też Henrykowi z Isernii). Zgodzić się jednak należy, że nawet jeśli sam manifest byłby tylko ćwiczeniem stylistycznym, oddawał on nastroje panujące na dworze praskim przed decydującym starciem z Rudolfem Habsburskim w 1278 r. z jednej strony (J. Žemlička, Přemysl Otakar II. Král na rozhraní věků, Praha 2011, s. 448), z drugiej zaś obrazuje, iż „tego typu argumentacja wydawała się właściwa wobec polskich elit politycznych" (T. Jurek, Polska droga do korony królewskiej 1295-1300-1320, w: Proměna stredovýchodní Evropy raného a vrcholného středověku. Mocenské souvislosti a paralely, red. M. Wihoda, L. Reitinger, Brno 2010, s. 151 n. i przyp. 44). Por też A. Barciak, Czechy, s. 140; idem, Problemy, s. 48 n. Nastroje te, formułowane już wcześniej m.in. we wspomnianych listach Kunegundy (przy konfliktach w zakonie franciszkańskim), mogły być znane i w części podzielane na gruncie polskim. 
domości narodowej wykazują, iż słowo „język” staje się w tym okresie (wiek XIII/XIV) synonimem słowa naród ${ }^{97}$, sugerując tym samym główne (lub jedno z najważniejszych) kryterium określania narodu ${ }^{98}$.

Działania integracyjne Kościoła wiązały się nie tylko ze wzrostem roli języka polskiego, za pomocą którego zamierzano oddziaływać szerzej na społeczeństwo polskie, ale i z pogłębianiem kultu św. Wojciecha jako patrona Polski, obok czego pojawiały się też dalsze pierwiastki narodowościowe, jak choćby obowiązek modlitwy za „spokój i pomyślność ojczyzny".

Pierwiastki te nie będą dziwić nie tylko ze względu na tło społeczne poprzedzające postanowienia, ale też osobę arcybiskupa, który w tym czasie stał na czele hierarchii polskiej. Omówionym synodom i radykalnej postawie duchowieństwa polskiego wobec zaistniałego konfliktu narodowościowego w Kościele na ziemiach polskich przewodniczył J. Świnka (1283-1314), uważany m.in. wskutek tego dość powszechnie w historiografii za obrońcę i propagatora polskości oraz idei zjednoczeniowych kraju ${ }^{99}$. Niechętna wobec Niemców postawa arcybiskupa jest nam dobrze znana, ponieważ odbiła się dość wyraźnie na kartach współczesnych mu źródeł ${ }^{100}$. Przypuszcza się, iż antyniemieckie stanowisko Świnki ukształtowało się wcześniej: jako współpracownik wielkopolskich Piastów mógł być

${ }_{97}$ B. Zientara, Wiek XIII, s. 73; por. idem, Cudzoziemcy, s. 23; H. Samsonowicz, op. cit., s. 622 . O rodzeniu się polskiej świadomości językowej patrz ostatnio, choć momentami dyskusyjnie, K. Maćkowiak, Początki polskiej świadomości językowej (X-XII wiek), "Język Polski" 86, 2006, s. 81-96.

98 Zob. M. Bláhová, Český národ ve staročeské kronice tak řečeného Dalimila, w: Historia vero, s. 635-653, tu 639; eadem, Národ, s. 30; S. Bylina, op. cit., s. 81; A. Janeczek, Świadomość wspólnoty słowiańskiej w pełnym i późnym średniowieczu, w: Słowianie - idea i rzeczywistość. Zbiór studiów, red. K. A. Makowski, M. Saczyńska, Poznań 2013, s. 35 n. (tu też omówienie innych wyznaczników tożsamości w źródłach średniowiecznych, s. 24-37).

99 Por. O. Balzer, Królestwo Polskie, t. 1, Lwów 1919, s. 306; W. Karasiewicz, op. cit., s. 328, 354; T. Silnicki, T. Gołąb, op. cit., s. 92; J. Bieniak, Zjednoczenie państwa polskiego, w: Polska dzielnicowa i zjednoczona. Państwo - społeczeństwo - kultura, red. A. Gieysztor, Warszawa 1972, s. 211; B. Zientara, Konflikty narodowościowe, s. 201; B. Nowacki, op. cit., s. 109 n.; S. Gawlas, „Verus heres”. Z badań nad świadomościa polityczna obozu Władysława Łokietka w początku XIV w., KH 95, 1988, 1, s. 93; J. Kurtyka, Odrodzone Królestwo. Monarchia Władysława Łokietka i Kazimierza Wielkiego w świetle nowszych badań, Kraków 2001, s. 16; J. Maciejewski, Episkopat polski doby dzielnicowej 1180-1320, Kraków 2003, s. 154-157; J. Krzyżaniakowa, Kultura umysłowa w czasach przełomu. Ośrodki - ludzie - dokonania, w: Polska około roku 1300. Państwo, społeczeństwo, kultura, red. W. Fałkowski, Warszawa 2003, s. 83, 85.

${ }^{100}$ Znamienna jest tu relacja kronikarza zbrasławskiego z koronacji Wacława II w Gnieźnie (Petra Žitavského Kronika Zbraslavská, w: Fontes Rerum Bohemicarum (dalej cyt. FRB), t. 4, wyd. J. Emler, Praha 1884, s. 82; por. Zbraslavská kronika, tł. F. Heřmanský, F. Mertlík, wstęp i oprac. Z. Fiala, Praha 1976, s. 119) czy postawa arcybiskupa w procesie wytoczonym krakowskiemu biskupowi Janowi Muskacie - o samym procesie i narodowościowych zarzutach wobec Muskaty zob. S. Gawlas, „Verus heres”, s. 82 nn. 
świadkiem i uczestnikiem konfliktów z Brandenburgią za Bolesława Pobożnego, obserwatorem sporów wewnętrznych między proniemieckim księciem kujawskim Siemowitem a odmawiającym mu posłuszeństwa z tego powodu rycerstwem, co więcej, współpracował z księciem uchodzącym za pogromcę Niemców ${ }^{101}$. Wcześniejsze zaangażowanie polityczne (w tym w ramach międzydzielnicowych) niewątpliwie pozwalało mu lepiej rozumieć problemy rozbitego państwa piastowskiego i czyhające zagrożenia, przekładające się też na sytuację w Kościele. Nasuwa się jednak zasadnicze pytanie: jakie znaczenie może mieć postawa arcybiskupa dla naszego problemu?

Nie sposób kwestionować faktu, iż w owym czasie idee propolskie i propaństwowe były dziełem nie tylko książąt, ale też w znacznej mierze wykształconych duchownych, do celów politycznych i ideologicznych zaś angażowano różnego rodzaju gatunki literackie, nie tylko historiografię, ale i piśmiennictwo religijne, np. hagiografię ${ }^{102}$. Program odnowienia królestwa i zjednoczenia Polski został wszak sformułowany najpełniej w Vita maior św. Stanisława pióra Wincentego z Kielczy, powstałym kilka lat po kanonizacji (1257-1261) ${ }^{103}$. To jednoczenie narodu wokół symboli religijnych nie powinno nas dziwić, słusznie podnosił już Kazimierz Tymieniecki, że w okresie bujnego rozkwitu religijności XIII w. „myśl patriotyczna polska w w. XIII nabiera cech religijności" ${ }^{104}$. Zgodzić się trzeba, że w Vita maior krakowskie środowisko duchownych, skupione wokół bp. Prandoty, uformowało dojrzałą koncepcję polityczną, którą złączono z nowo kanonizowanym męczennikiem, wykreowanym na świętego narodowego i orędownika dzieła zjednoczenia. To niewątpliwie podnosiło rangę ośrodka krakowskiego, zwłaszcza że właśnie w Krakowie, jak zaznaczał hagiograf, znajdowały się insygnia królewskie dla oczekiwanego zjednoczyciela pań-

101 B. Nowacki, op. cit., s. 113.

102 D. Rychlewicz, L'hagiographie polonaise au Moyen Âge et la propagande politique, w: Le rôle des médias à travers l'histoire. Actes du VIIIe Colloque Poznań-Strasbourg 12-14 mai 1994, red. M. Serwański, Poznań 1995, s. 49-60; patrz też przyp. 103.

${ }^{103}$ Vita sancti Stanislai Cracoviensis episcopi (vita maior), wyd. W. Kętrzyński, MPH, t. 4, Lwów 1884, s. 392-393; Żywot większy św. Stanisława, w: Średniowieczne żywoty i cuda patronów Polski, tł. J. Pleziowa, wstęp i kom. M. Plezia, Warszawa 1987, s. 282-283. Koncepcja ta kształtowała się stopniowo już w poprzedzającym czasie, z braku miejsca na szersze omówienie odsyłamy do wyczerpującego najnowszego omówienia problemu formowania się koncepcji zjednoczeniowych w piśmiennictwie (ale i z wykorzystaniem zabytków materialnych) Wojciecha Drelicharza, Idea zjednoczenia królestwa w średniowiecznym dziejopisarstwie polskim, Kraków 2012 (s. 112-123 omówienie dyskusji nad datacją żywotów św. Stanisława).

${ }^{104}$ K. Tymieniecki, Pierwsze wskrzeszenie państwa polskiego a ideologia średniowieczna, w: Książa zbiorowa ku uczczeniu Pierwszej Rocznicy istnienia Uniwersytetu Poznańskiego, red. T. Grabowski, Poznań 1920, s. 33. 
stwa $^{105}$. Połączenie nowego świętego z koncepcją zjednoczenia bez wątpienia wzajemnie wzmacniało obie idee ${ }^{106}$, co zresztą dość wyraźnie widać w rozwoju kultu Stanisława: początkowo miał być wszak lokalnym patronem diecezji krakowskiej, ale szybko zyskiwał funkcję patrona ogólnopolskiego ${ }^{107}$. Niemniej jednak we wczesnym okresie koncepcję tę cechował partykularyzm ${ }^{108}$.

Abp J. Świnka i środowisko gnieźnieńskie musiało zdawać sobie sprawę z faktu, iż wyniesienie bp. Stanisława i aktywne promowanie jego kultu było reakcją środowiska krakowskiego, współzawodniczącego z Gnieznem, na kult św. Wojciecha, tym samym wcześniejsza rywalizacja między ośrodkiem gnieźnieńskim a krakowskim uległa zaostrzeniu ${ }^{109}$. Odpowiedzią na te działania były najprawdopodobniej powstałe w środowisku gnieźnieńskim Miracula sancti Adalberti ${ }^{110}$, datowane na lata 1260 a 1295 i wyrażające stanowisko wielkopolskich duchownych wobec starań zmierzających do wykreowania krakowskiego biskupa na patrona całego kra$\mathrm{ju}$, ale i wobec powiązania z nim idei zjednoczenia politycznego ${ }^{111}$. Zauważono już bowiem, że nie były one jedynie przypomnieniem patrona, ale - wykorzystując różne źródła, w tym żywoty Stanisława - stworzono w nich nowy wzorzec: św. Wojciech jest tu misjonarzem państwa, ,jego

${ }^{105}$ W. Drelicharz, op. cit., s. 112-199, zwł. 148 n., 197 n.

106 Ibidem, s. 198.

${ }^{107} \mathrm{Na}$ temat funkcji nowego świętego istnieje już dość obszerna literatura, wskażmy jedynie kilka pozycji: J. Kłoczowski, Święty Stanisław a umacnianie polskiej świadomości narodowej i religijnej w XIII wieku, „Znak” 31, 1979, 298/299 (4/5), s. 308-318; Z. Piech, Święty Stanisław szafarzem korony Królestwa Polskiego, „Rocznik Krakowski” 57, 1991, s. 5-17; M. R. Pauk, Kult św. Stanisława na tle innych kultów politycznych Europy Środkowej, w: Kult św. Stanisława na Śląku (1253-2003), red. A. Pobóg-Lenartowicz, Opole 2004, s. 45 nn.; A. Rożnowska-Sadraei, Pater Patriae. The Cult of Saint Stanislaus and the Patronage of Polish Kings 1200-1455, Kraków 2008.

108 J. Maciejewski, op. cit., s. 154.

${ }_{109}$ G. Labuda, Święty Wojciech w literaturze i legendzie średniowiecznej, w: Święty Wojciech, 997-1947. Księga pamiątkowa, red. Z. Biernacki i in., Gniezno 1947, s. 89-112, przedruk: Święty Wojciech w polskiej tradycji historiograficznej, wybór i oprac. G. Labuda, Warszawa 1997, s. 219 (cyt. ostat. wyd.); G. Gromadzki, Legenda De sancto Adalberto episcopo oraz Miracula sancti Adalberti. Studium źródłoznawcze, RHum 37, 1989, z. 2, s. 6 n., 9 n.

${ }^{110}$ Miracula sancti Adalberti, wyd. W. Kętrzyński, MPH, t. 4, s. 221-238. Chodzi tu w istocie o nowy żywot św. Wojciecha, w którym Miracula stanowią tylko końcową część utworu, jego początek (właściwy żywot) nie został dotychczas w całości wydany; problem omawia ostatnio W. Drelicharz, op. cit., s. 243 n.; o edycjach zob. też A. Witkowska, J. Nastalska, Święty Wojciech. Życie i kult. Bibliografia do roku 1999, Lublin 2002 , s. 45 n.

111 O datacji i uwarunkowaniach powstania zob. G. Labuda, Święty Wojciech, s. 218 n.; G. Gromadzki, op. cit., s. 9 n.; W. Drelicharz, op. cit., s. 245-256 (który zawęża ją do 1280-1281 r.); por. P. Wiszewski, Rex in regno suo? Wokół wyobrażeń i propagandy władzy królewskiej Piastów (do 1296 r.), w: Proměna středovýchodní Evropy, s. 458-460. 
duszpasterzem, założycielem polskiej hierarchii kościelnej”, co czyniło z niego „bohatera narodowego"112. Co nie mniej ważne, to z Wojciechem połączono zasługę uzyskania przez Polskę korony królewskiej w 1000 r., a więc w opozycji do krakowskiej związanej ze św. Stanisławem zaprezentowana tu została nowa koncepcja historiograficzna i zjednoczeniowa, eksponująca role Gniezna i jego patrona jako „szafarza korony”113. Przypomnijmy, że również statuty synodu łęczyckiego utrwalały kult Wojciecha, nakazując, by wszystkie kościoły katedralne i konwentualne w Polsce posiadały hystoria beati Adalberti, która miała być publicznie śpiewana czy recytowana ${ }^{114}$ - było to prawdopodobnie rymowane oficjum o św. Wojciechu, wykonywane w trakcie godzin kanonicznych, zazwyczaj przez przez chór kapitulny czy monastyczny, na uroczystości świętego (23 kwietnia i 20 października) ${ }^{115}$. To zaś, jak zauważa Wojciech Drelicharz, zmuszało też do lektury legend brewiarzowych poświęconych męczennikowi, zatem utrwalało znajomość hagiografii świętowojciechowej przynajmniej w grupie kleru katedralnego czy zakonnego, który mógł kształtować opinię reszty społeczeństwa ${ }^{116}$ - a dodajmy, że nowy żywot znalazł dość szerokie zastosowanie $w$ liturgii brewiarzowej ${ }^{117}$. Zasadne jest też spostrzeżenie, że utwory religijne miały - ze względu na wykorzystywanie w liturgii większą siłę oddziaływania niż zabytki dziejopisarskie, zwłaszcza te odnoszące się do popularnych kultów mogły służyć szerszemu propagowaniu określonych treści politycznych ${ }^{118}$.

Niewątpliwie kult wspólnych danemu obszarowi patronów stanowi jeden z czynników przejawiającej się świadomości narodowej (służący identyfikacji narodowej) ${ }^{119}$, istnienie zaś jednego patrona, co już podkreślał Oswald Balzer, stanowi silny łącznik integrujący społeczeństwo,

112 G. Gromadzki, op. cit., s. 62 n., 68-70.

113 G. Labuda, Święty Wojciech, s. 219; G. Gromadzki, op. cit. O koncepcji tej i wcześniejszych przejawach rodzenia się w Wielkopolsce ideologii zjednoczeniowej patrz też W. Drelicharz, op. cit., s. 241-243, 246.

114 SPPP, t. 1, s. 384; KDW, t. 1, nr 551, s. 511; na rolę tego aspektu w gnieźnieńskiej koncepcji zjednoczeniowej zwracała uwagę Jadwiga Krzyżaniakowa, op. cit., s. 83.

${ }^{115}$ B. Gładysz, Statut synodu łęczyckiego z r. 1285 o ,historii b. Adalberti” w nowym oświetleniu, „Sprawozdania Poznańskiego Towarzystwa Przyjaciół Nauk” 8, 1934, nr 1/2, s. 6-10; W. Danielski, Kult św. Wojciecha na ziemiach polskich $w$ świetle przedtrydenckich ksiag liturgicznych, Lublin 1997, s. 42 (tu omówione elementy tego oficjum s. 165 nn.).

116 W. Drelicharz, op. cit., s. 258-265.

117 W. Danielski, op. cit., s. 37-65; W. Drelicharz, op. cit., s. 244.

118 D. Rychlewicz, op. cit., s. 50, 52 nn.; W. Drelicharz, op. cit., s. 257 nn.

119 Por. przykładowo B. Nowacki, op. cit., s. 108; M.R. Pauk, Święci patroni a średniowieczne wspólnoty polityczne w Europie Środkowej, w: Sacrum. Obraz i funkcja w społeczeństwie średniowiecznym, red. J. Pysiak, A. Pieniądz-Skrzypczak, Warszawa 2005, s. 237-260; M. Bláhová, Národ, s. 29; H. Samsonowicz, op. cit., s. 625. 
państwo czy naród ${ }^{120}$. Tymczasem w drugiej połowie XIII w. nie tylko na gruncie politycznym, ale i religijnym, tj. w zakresie propagowanych kultów, dwie główne prowincje państwa stanęły w opozycji, walcząc o pierwszeństwo. Zauważmy też, iż w ramy tej swoistej rywalizacji włączył się również Śląsk, albowiem wskutek kanonizacji w 1267 r. Kościół wrocławski uzyskał własną świętą, tj. św. Jadwigę. Nowe kulty (św. Stanisław, św. Jadwiga), choć z początku lokalne wobec ogólnopolskiego patrona św. Wojciecha, niewątpliwie służyły ugruntowaniu pozycji poszczególnych dzielnic (ich książąt i elit, również duchownych) i wspierały ideologicznie działania zmierzające do konsolidacji kraju i korony królewskiej, z mniejszym lub większym sukcesem prowadzone przez poszczególnych książąt dzielnicowych, czy idee zjednoczeniowe kreowane w oparciu o poszczególne ośrodki ${ }^{121}$.

Z perspektywy ośrodka gnieźnieńskiego były to niewątpliwie czynniki konkurencyjne, przede wszystkim marginalizujące rolę Gniezna, ale też zapewne osłabiające integralność społeczeństwa. Z drugiej zaś strony badacze nie mają wątpliwości, iż w programie politycznym J. Świnki przejawiały się wyraźne tendencje zjednoczeniowe, ujawnione zresztą podczas współpracy z Przemysłem II - arcybiskup nie tylko patronował jego zabiegom zmierzającym do koronacji, ale też czynnie je wspierał ${ }^{122}$.Jednak po rychłej śmierci Przemysła II czy rządach czeskich program zjednoczeniowy z konieczności musiał ulec modyfikacji w wizji jego współtwórcy, zwłaszcza wobec braku dynastycznych wielkopolskich kontynuatorów dzieła. Nasuwa się więc wniosek, iż na fali walki o polskość z jednej strony oraz propagowania ideologii zjednoczeniowej i szukania czynników jednoczących różne prowincje rozbitego państwa z drugiej, pojawiło się zapotrzebowanie nie tylko na obronę języka, ale i na patronat oraz ochronę uniwersalną, której nie podważałyby lokalne rywalizacje w zakresie kultu. Takim zaś z pewnością był kult Maryi Matki Bożej, której wielka rola jako pośredniczki między Bogiem a ludźmi objawia się już w początkach

120 Por. O. Balzer, op. cit., t. 1, s. 94.

${ }^{121}$ J. Dowiat, Historia Kościoła, s. 163; J. Bieniak, op. cit., s. 217 n. Rywalizację nie tylko polityczną, ale i ideową wszystkich trzech dzielnic za pomocą dzieł historiograficznych „o prawa swoich książąt do berła” dostrzegała już Brygida Kürbis, Ze studiów nad kultura historyczna wieków średnich w Polsce, St. Źr. 3, 1958, s. 51. Ostatnio o politycznej roli wszystkich trzech wzmiankowanych kultów patrz W. Mrozowicz, Die politische Rolle des Kultes des hl. Adalbert, Stanislaus und der hl. Hedwig im Polen des 13. Jahrhunderts, w: Fonction sociales et politiques du culte des saints dans les sociétés de rite grec et latin au Moyen Âge et á l'époque moderne. Approche comparative, red. M. Derwich, M. Dmitriev, Wrocław 1999, s. 111-124.

122 O. Balzer, op. cit., t. 1, passim; J. Bieniak, op. cit., s. 222, 227 n.; B. Nowacki, Przemysł II odnowiciel Korony Królestwa Polskiego (1257-1296), Kraków 2007, s.175-183, 188 n., 199. 
chrześcijaństwa ${ }^{123}$ i która towarzyszyła od początku rodzącemu się chrześcijaństwu i Kościołowi polskiemu ${ }^{124}$. Poświadczają to najstarsze wezwania kościołów (m.in. w czołowych ośrodkach, tj. w Gnieźnie, Poznaniu, Krakowie), ślady jej kultu w najstarszym piśmiennictwie (hagiografia św. Wojciecha, Modlitewnik Gertrudy) i liturgii. Kult ten systematycznie umacniał się w kolejnych stuleciach, jak świadczy wzrastająca liczba świąt poświęconych Maryi ${ }^{125}$. Wyobrażeń maryjnych nie brakowało też w symbolice władzy (na pieczęciach, monetach) ${ }^{126}$.

Czy podobną funkcję mógł spełniać kult św. Jana Chrzciciela? Pozytywną odpowiedź daje prześledzenie problemu dokonane przez Romana Mazurkiewicza ${ }^{127}$. Również ten kult pojawił się na ziemiach polskich w początkach chrystianizacji, propagowany zapewne przez pierwszych benedyktynów, potem joannitów, norbertanów, augustianów-eremitów czy franciszkanów, nie brakowało też innych dróg jego popularyzacji (kontakty z Zachodem i Wschodem) ${ }^{128}$. Z perspektywy wezwań kościelnych wynika, iż szczególną popularnością cieszył się on na śląsku (do ważniejszych należy wezwanie katedry wrocławskiej; ogólnie doliczono się ponad 70 kościołów i kaplic w średniowieczu) ${ }^{129}$. Do XIII w. nie brakuje jednak świętojańskich patrociniów w Wielkopolsce (z ważniejszych np. w Gnieźnie, Gieczu, Mogilnie) i Małopolsce (np. w Krakowie, Sandomierzu, Zawichoście); pojawia się wreszcie na Pomorzu (np. ka-

${ }^{123}$ F. Dziasek, Wszechpośrednictwo Najśw. Maryi Panny, w: Gratia plena. Studia teologiczne o Bogurodzicy, red. B. Przybylski, Poznań-Warszawa-Lublin 1965, s.303-340, zwł. 325 n.

${ }^{124}$ T. Dunin-Wąsowicz, Kulty świętych $w$ Polsce $w$ X w., w: Polska $w$ świecie. Szkice z dziejów kultury polskiej, red. J. Dowiat i in., Warszawa 1972, s. 62.

125 Por. J. Wojnowski, Rozwój czci Matki Bożej w Polsce, „Homo Dei” 26, 1957, nr 6, s. 846-862; C. Deptuła, Z zagadnień historii kultu maryjnego w Polsce, „Ateneum Kapłańskie" 60, 1960, s. 392-419; Historia Kościoła w Polsce, t. 1, cz. 1, s. 34, 431; B. Kumor, Powstanie i rozwój sieci parafialnej w Małopolsce południowej do końca XVI wieku, „Prawo Kanoniczne” 1963, nr 1/4, s. 443-445; najszerzej ostatnio R. Mazurkiewicz, Deesis. Idea wstawiennictwa Bogarodzicy i św. Jana Chrzciciela w kulturze średniowiecznej, Kraków 1994, s. $118-120$.

${ }^{126}$ Z. Piech, Ikonografia pieczęci Piastów, Kraków 1993 (wg indeksu); J. Stachowiak, Motywy maryjne na monetach europejskich od IX do XX wieku, „Archiwa, Biblioteki i Muzea Kościelne" 1981, 43, s. 117; dla miast śląskich śledzi ostatnio Przemysław Wiszewski (The Effigies of the Blessed Virgin Mary or Saints on the Medieval Seals of Silesian Cities and Towns (Since the $13^{\text {th }}$ to the Middle of the $16^{\text {th }}$ Century), w: Fonction sociales, s. 183-208), choć tu wyobrażenia odnotowuje od XIV w. (por.s. 205).

${ }_{127}$ R. Mazurkiewicz, op. cit., s. 120-137.

${ }^{128}$ Ibidem, s. 120-123; por. T. Silnicki, Dzieje i ustrój, s. 20 n.; T. Dunin-Wąsowicz, op. cit., s. 62.

${ }^{129}$ H. Neuling, Schlesiens Kirchorte und ihre kirchlichen Stiftungen bis zum Ausgange des Mittelalters, Breslau 1902 (choć w świetle nowszych badań liczbę tę zapewne można by zweryfikować); zob. też T. Silnicki, Z dziejów Kościoła w Polsce. Studia i szkice historyczne, Warszawa 1960, s. 21; R. Mazurkiewicz, op. cit., s. 125 n. 
tedra w Kamieniu Pomorskim $)^{130}$. Jako pomoc datacyjna w odniesieniu do Bogurodzicy może służyć fakt, iż w XIV w. liczba patrociniów św. Jana, „należącego w okresie romańskim do najbardziej po Bogarodzicy czczonych świętych, zgodnie ze starożytną ideą Trina Sanctitas" (jak stwierdza R. Mazurkiewicz), zaczyna maleć, w związku z rozwojem lokalnych kultów, rzadziej też mamy do czynienia ze wspólnymi wezwaniami Marii i Jana ${ }^{131}$. W literaturze religijnej (oficjalnej i nieoficjalnej) zjawisko to będzie zauważalne w wieku XIV i XV ${ }^{132}$. Niemniej w okresie wcześniejszym św. Jan pojawia się także w mennictwie książęcym (już za Bolesława Śmiałego) i na pieczęciach (biskupich i kapituły wrocławskiej, niektórych miast śląskich) ${ }^{133}$. Mamy też ślady istnienia jego relikwii na ziemiach polskich czy obecności w rzeźbie ${ }^{134}$. W kalendarzach kościelnych św. Jan posiada najwięcej - po Maryi - świąt, pojawiał się trwale w liturgii mszalnej, zaznaczał się w prywatnej dewocji dworów książęcych w drugiej połowie XIII w. ${ }^{135}$ Już Brückner zwracał uwagę na św. Kingę i szczególną część, jaką miała żywić dla Bogarodzicy i Jana Chrzciciela ${ }^{136}$. Jak się wydaje, kult św. Jana bywał zjawiskiem nie tylko z zakresu liturgii, ale i ideologii politycznej, co potwierdzałaby tytulatura Henryka Brodatego w jednym z dokumentów („Ego Henricus Dei et beati Johannis gratia Zlesiae dux") ${ }^{137}$.

Powyższe dywagacje nad kultem Maryi i św. Jana wiążą się z faktem, iż w kontekście Bogurodzicy już A. Brückner zwracał uwagę, że stanowi ona swoisty komentarz do grecko-bizantyjskiego motywu deesis ${ }^{138}$. Deesis,

130 B. Kumor, Powstanie i rozwój, s. 447; J. Nowacki, Dzieje archidiecezji poznańskiej, t. 2: Archidiecezja poznańska w granicach historycznych i jej ustrój, Poznań 1964, s. 351-353; R. Mazurkiewicz, op. cit., s. 125 n.

${ }^{131}$ R. Mazurkiewicz, op. cit., s. 126.

${ }^{132}$ Ibidem, s. 135-137.

133 Por. M. Gumowski, Pieczęcie śląskie do końca XIV w., w: Historia Śląska od najdawniejszych czasów do roku 1400, t. 3, red. W. Semkowicz, Kraków 1936, s. 247-440; idem, Moneta na Śląsku do końca XIV w., w: Historia Śląska, s. 533-717 (według indeksu); M. Okunek, Motywy chrześcijańskie w ikonografii monet polskich około 980-1173 r., „Archiwa, Biblioteki i Muzea Kościelne" 1994, 63, s. 305 n.; P. Wiszewski, The Effigies, passim; S. Suchodolski, Poczatki mennictwa we Wrocławiu, w: Słowiańszczyzna w Europie średniowiecznej, red. Z. Kurnatowska, t. 2, Wrocław 1996, s. 121-126; B. Paszkiewicz, Pieniądz górnosląski w średniowieczu, Lublin 2000, s. 21, 201.

${ }_{134}$ R. Mazurkiewicz, op. cit., s. 123 nn.

135 Ibidem, s. 127-134.

${ }^{136}$ A. Brückner, Bogurodzica, s. 120 n.

${ }^{137}$ Kodeks dyplomatyczny Śląska, t. 1, wyd. K. Maleczyński, Wrocław 1956, nr 99, s. 236; B. Zientara, Henryk Brodaty i jego czasy, Warszawa 1975, s. 299 n.; R. Mazurkiewicz, op. cit., s. 125.

138 A. Brückner, Dzieje języka, s. 101; idem, Bogurodzica, w: idem, Encyklopedia staropolska, t. 1, Warszawa 1939, s. 104 n.; por. R. Mazurkiewicz, op. cit., s. 192 nn. 
przypomnijmy, to kompozycja wyobrażająca Chrystusa jako Zbawiciela i sędziego, po bokach którego w modlitewnych pozach znajdują się Maryja i św. Jan Chrzciciel jako orędownicy ${ }^{139}$. Gruntowną analizę obecności tego motywu w kulturze średniowiecznej przeprowadził wspomniany R. Mazurkiewicz, zacytujmy więc jego ustalenia:

możemy przyjąć, że pieśń ta spełnia wszystkie [--] warunki uznania jej za literacki odpowiednik przedstawienia Deesis: zbiorowość wiernych zwraca się do Chrystusa - ostatecznego adresata pieśni - z modlitwą o charakterze uniwersalnym: o „zbożny pobyt na świecie” i „rajski przebyt po żywocie"; orędownikami tej modlitwy są Matka Boża i św.Jan Chrzciciel, przy czym Maria jest zarazem pośredniczką i adresatką prośby wyrażonej w pierwszej zwrotce, Jan natomiast pośredniczy jedynie (przez swe zasługi) w prośbie skierowanej do Chrystusa w drugiej zwrotce ${ }^{140}$.

Już J. Woronczak zwracał uwagę na obecność tego motywu na powstałych przed $1161 \mathrm{r}$. malowidłach absydy kolegiaty w Tumie pod Łęczycą, wyobrażających Chrystusa-Pankratora zasiadającego na tronie, po prawicy którego znajduje się z uniesionymi modlitewnie rękami Bogarodzica, po lewicy zaś św. Jan Chrzciciel ${ }^{141}$. Jak wynika z dotychczasowych badań, najstarsze wyobrażenia deesis w Polsce odpowiadają tzw. fali bizantyńskiej na Zachodzie i zamykają się w granicach czasowych od połowy XII do połowy XIII w. ${ }^{142}$ Motyw deesis w różnych konfiguracjach (np. idea Maiestas Domini, motyw Sądu Ostatecznego) jest uchwytny również w innych sakralnych obiektach XII i XIII (kościoły w Siewierzu - połowa XII w., Czerwińsku i Dobrocinie - pierwsza połowa XIII w.), malarstwie miniaturowym (psałterz trzebnicki z ok. 1240 r.) ${ }^{143}$. Sposób kompozycji motywu skłania R. Mazurkiewicza do wniosku o „,szybkiej i automatycznej niejako asymilacji na gruncie wczesnego polskiego średniowiecza idei pierwszorzędnej roli Maryi i Jana Chrzciciela jako orędowników całego

${ }^{139}$ H. Madej, Deesis, w: Encyklopedia katolicka, t. 3, Lublin 1979, kol. 1086-1088.

140 R. Mazurkiewicz, op. cit., zwł. 171 (ze szczegółową interpretacją tekstu s. 170-192).

${ }^{141}$ O malowidłach zob. A. Dąbrowski, Odkrycie romańskiej polichromii w Tumie pod Łęczyca, „Ochrona Zabytków” 5, 1952, nr 4, s. 240-252; M. Walicki, Dekoracja architektury i jej wystrój artystyczny, w: Sztuka polska przedromańska i romańska do schyłku XIII wieku, red. idem, t. 1, Warszawa 1971, s. 230 n.; E. Roznerska-Świerczewska, Problematyka konserwacji restauracji i rekonstrukcji malowidła ściennego „Sąd Ostateczny” z absydy zachodniej $z$ archikolegiaty $w$ Tumie pod Łęczyca, w: 850 lat w służbie Bogu i ludziom. Archikolegiata Łęczycka w Tumie, red. M. Żemigała, Łęczyca-Tum 2011, s. 46; J. Jarzewicz, Kościoły romańskie w Polsce, Kraków 2014, s. 112.

${ }^{142}$ R. Mazurkiewicz, op. cit., s. 138.

${ }^{143}$ Ibidem, s. 141-143. 
rodzaju ludzkiego przed Chrystusem"144. Nie sposób nie dostrzec, że ta konstatacja współgra z innymi śladami kultu Maryi, a zwłaszcza św.Jana. W dalszej kolejności warto przypomnieć, że kolegiata w Tumie pod Łęczycą to miejsce, w którym począwszy od 1180 r., odbywały się synody prowincjonalne zwane łęczyckimi pod patronatem arcybiskupów, w tym również J. Świnki ${ }^{145}$. Możemy więc pokusić się o przypuszczenie, że to, a może również inne wyobrażenia deesis w sztuce ${ }^{146}$ nie tylko utrwalały owe fundamentalne kulty chrześcijańskie, ale mogły też być inspirujące przy poszukiwaniu czynników jednoczących rozbite na dzielnice państwo z lokalnymi kultami.

Bogurodzica, w swej pierwotnej, dwuzwrotkowej postaci, spełniała dwie główne funkcje. Pierwszą można powiązać z dążnością do ochrony i propagowania języka polskiego, tak silnie zaznaczoną przez polskie duchowieństwo w omawianych statutach synodalnych. Nie ulega wątpliwości, iż rozwój literatury w języku narodowym służy pogłębieniu świadomości narodowej ${ }^{147}$, do czego najwyraźniej zdążał abp J. Świnka. Druga funkcja wiązała się z potrzebą znalezienia dodatkowego czynnika integrującego społeczeństwo różnych dzielnic w postaci wspólnych im kultów, co w dobie rywalizacji kultów dzielnicowych z jednej strony oraz wyraźnego zapotrzebowania na ideologię zjednoczeniową z drugiej, nie było bez znaczenia.

Przypomnijmy jednocześnie, że najstarszy rękopis Bogurodzicy wykazuje związki z metropolią gnieźnieńską. Zachował on też poprawniejsze formy niż drugi, a bliski mu krakowski oraz opierająca się na nim tradycja, co może oznaczać, że w środowisku gnieźnieńskim była dostępna wersja bliższa oryginałowi. Zauważmy też, że promocja języka polskiego zainicjowana przez J. Świnkę wynikała z konfliktów narodowościowych schyłku XIII i początku XIV w. Jest chyba nie bez znaczenia, że w początkowym okresie pieśń ta związana była $\mathrm{z}$ dwoma środowiskami: duchowieństwem i rycerstwem. Jakkolwiek zaś zasięg antyniemieckich nastrojów polskiego społeczeństwa i związane z nim formowanie się świadomości narodowej bywają dyskusyjne, to jednak nawet ostrożni badacze są zgodni, iż rodziły

144 Ibidem, s. 144

145 T. Silnicki, K. Gołąb, op. cit., s. 100; P. Krafl, op. cit., s. 10; o kolegiacie, jej dziejach i roli ostatnio J. Szymczak, Pierwsze cztery wieki Archikolegiaty Łęczyckiej, w: 850 lat, s. 9-21, tu s. 17, 30.

146 W. Smoleń, Maryja Panna w naszych sztukach plastycznych, w: Gratia plena, s. 487501, zwł. s. $488 \mathrm{nn}$.

${ }^{147}$ B. Zientara, Konflikty, s. 212. 
się one przede wszystkim wśród rycerstwa i duchowieństwa ${ }^{148}$, a więc tych samych grup, z którymi możemy powiązać Bogurodzicę.

Można oczywiście zapytać, dlaczego w pierwszej pieśni polskiej, która wyszłaby ze środowiska gnieźnieńskiego, nie promowano kultu św. Wojciecha. Zapewne decydowała o tym świadomość lokalnych rywalizacji. Zauważmy też przy tym, że w sąsiednich Czechach, choć nie brak świętych patronów, spośród których do rangi głównego opiekuna państwa wyrasta św. Wacław, wieczny książę Czechów, wspomagający rycerstwo czeskie w bitwach ${ }^{149}$, choć nie brak poświęconej mu literatury i pieśni, to jednak przy najważniejszych uroczystościach kościelnych i państwowych była inicjowana pieśń Hospodine pomiluj ny, wzywająca najwyższej opieki i ochrony ojczyzny. Śpiewało ją też rycerstwo, idąc do boju. O ile zaś pierwsza zwrotka Bogurodzicy to pieśń maryjna, najwyższym jej adresatem, uwidaczniającym się w drugiej zwrotce, jest Chrystus.

Sięgnijmy jeszcze do podnoszonych wielokroć analogii czeskich i potencjalnie wzorcowej roli pieśni Hospodine pomiluj ny ${ }^{150}$. Wokół jej powstania również toczą się spory (datacja waha się od IX do XII w.) ${ }^{151}$, jednak

148 Idem, Cudzoziemcy, s. 21; idem, Konflikty, s. 205 n.; J. Bieniak, op. cit., s. 214; por. też O. Balzer, op. cit., t. 1, s.148; S. Gawlas, Społeczny, s. 658-660; szerszy zasięg przyjmował R. Heck, op. cit., s. 6 nn.

${ }^{149}$ F. Graus, Die Heilige als Schlachthelfer, w: Festschrift für Helmut Beumann, red. K.-U. Jäschke, R. Wenskus, Sigmaringen 1977, s. 330-348; idem, St. Adalber und St. Wenzel. Zur Funktion der mittelalterlichen Heiligenverehrung in Böhmen, w: Europa slavica - Europa orientalis. Festschrift für Herbert Ludat zum 70. Geburtstag, red. K.-D. Grothusen, K. Zernack, Berlin 1980, s. 205-231; J. Žemlička, Svatý Václav jako věčný kniže „Čechů”, w: Svatý Václav. Na památku 1100. výročí narození knižete Václava Svatého, red. P. Kubín, Praha 2010 , s. 211-220.

${ }^{150}$ Co przyznał w końcu nawet sceptyczny A. Brückner, Prawda o „Bogurodzicy”, „Ruch Literacki” 11, 1936, nr 3, s. 68; zależności przyjmują też badacze czescy, por. J. Macůrek, La mission byzantine en Moravie au cours des années 863-885 et la portée de son héritage dans l'histoire de nos pays et de l'Europe, w: Magna Moravia. Sborník k 1100. výročí príchodu byzantské mise na Moravu, red. idem i in., Praha 1965, s. 17-70, tu s. 52.

${ }^{151}$ A. Škarka, Nejstarší česká duchovní lyrika, Praha 1949, s. 27 n.; D. Orel, Hudební prvky svátovaclavské, Praha 1937, Svatováclavský sborník, t. 2.3, s. 4-67; J. Racek, Sur la question de la genèse du plus ancien chant liturgique tchèque „Hospodine, pomiluj ny”, w: Magna Moravia, s. 435-460, zwł. 450, 459 n.; F. W. Mareš, Analiza tekstologiczna pieśni Hospodine, pomiluj ny, „Sprawozdania z Posiedzeń Komisji Naukowej Oddziału PAN w Krakowie” 11, 1967, z. 2, s. 694-696; idem, Hospodine, pomiluj ny, w: idem, Cyrilometodějská tradice a slavistika, Praha 2000, s. 403-460; V. Konzal, Církevněslovanská literatura - slepá ulička na prahu české kultury?, w: Speculum medii aevi, red. L. Juroušková, Praha 1998, s. 154 nn. Wynika to z faktu, że pierwszy zapis pochodzi ze zbioru modlitw kaznodziei Milicza (Knihovna pražské metropolitní kapituly, Praha, sygn. NUK XVII, F 30, fol. 96a) w rękopisie z ok. 1380 r., muzykę i tekst po raz pierwszy zapisał brzewnowski mnich Jan z Holešova w 1397 r. 
przedmiotem naszych zainteresowań będzie przede wszystkim jej funkcja. Istotne jest bowiem, że poczynając od XIII w., możemy mówić o jej popularyzacji w społeczeństwie czeskim. Po raz pierwszy mamy wzmiankę w Drugiej Kontynuacji Kosmasa, przy opisie wydarzeń z lat 1248-1249, kiedy to po stłumieniu powstania syna Przemysła Ottokara II Wacław I wkraczał na Praski Gród do kościoła, lud i możni śpiewają zaś Hospodine pomiluj ny ${ }^{152}$. Dalsze informacje o jej śpiewie dotyczą bitew (pod Kressenbrun i na Morawskim Polu ${ }^{153}$, przybycia nowo wyświęconego bp. Tobiasza, powrotu Wacława uwięzionego przez opiekuna margrabiego Ottona brandenburskiego (1283) ${ }^{154}$. Doceniając rolę pieśni, Karol IV włączył ją do ceremoniału koronacyjnego, w 1358 r. zaś przyznany został za jej śpiewanie odpust (analogicznie jak około 100 lat później Bogurodzicy) ${ }^{155}$.Z naszej perspektywy istotne jest, że pieśń ta pojawia się przy okazji przełamywania konfliktów wewnętrznych, w obliczu zagrożenia zewnętrznego przed bitwami, wreszcie odzyskania następcy tronu. Zatem we wszystkich chwilach ważnych dla trwałości i integralności państwa lud czeski wzywał najwyższego wsparcia, śpiewając Hospodine pomiluj ny.

Dość liczne kontakty polsko-czeskie sprawiały, że zapewne było wiele możliwości zapoznania się z tą pieśnią i jej nie tylko religijną, ale i polityczną funkcją. W kampanii z roku 1260 po stronie Przemysła Ottokara II uczestniczyły wojska polskie sojuszników śląskich ${ }^{156}$, również w bitwie pod Suchymi Krutami brały udział posiłki polskie ${ }^{157}$. A. Barciak zwrócił uwagę na niezwykle częste kontakty duchowieństwa obu krajów w XIII w., zarówno zakonnego (wzmacniane wspólnymi prowincjami czy czeskimi macierzami części polskich fundacji), jak i świeckiego. Do zacieśniania kontaktów przyczyniało się łączenie godności duchownych w Polsce i Czechach - przykładowo w skład kapituły praskiej wchodzili Mikołaj - scholastyk krakowski, późniejszy biskup poznański, czy Jan z Wrocławia, będący też kapelanem księcia kujawskiego i kanonikiem poznańskim ${ }^{158}$. Wreszcie zaproponowanie korony polskiej Wacławowi II musiało wiązać się z wizytami polskich posłów - wśród

152 Přiběhy krále Wácslawa I., w: FRB, t. 2.2, wyd. J. Emler, Praha 1874, s. 308.

153 Přiběhy krále Přmysla Otakara II, w: FRB, t. 2, s. 319; Ottokars Österreichische Reimchronik, wyd. J. Seemüller, Hannover 1890, MGH Deutsche Chroniken, t. 5.1, s. 214 (z nieco zdeformowanym tytułem: „ozpodina pomyloydo”).

${ }^{154}$ Wyprawowání o zlých létech po smrti krále Přemysla Otakara II (B), w: FRB, t. 2, s. $339,366$.

155 Omawiają: J. Racek, op. cit., s. 438, 450; S. Urbańczyk, „Bogurodzica”, s. 123; patrz przyp. 162.

156 Př́běhy krále Přemysla, s. 311 n.; B. Włodarski, op. cit., s. 33; J.Žemlička, Přemysl, s. 111.

157 Př́běhy krále Přemysla, s. 330 n.; T. Jurek, op. cit., s. 161; J.Žemlička, Přemysl, s. 458 n.

${ }^{158}$ A. Barciak, Czechy, s. 40. 
których zapewne byli też duchowni - na dworze czeskim ${ }^{159}$. Tu można wysunąć nieco śmiałe przypuszczenie, że również sam arcybiskup mógł zetknąć się w Pradze z pieśnią Hospodine, goszcząc tam osobiście ${ }^{160}$, skoro była ona śpiewana przez lud w dni świąteczne i niedziele podczas procesji ${ }^{161}$. Czy dzięki kontaktom bezpośrednim arcybiskupa, czy duchowieństwa polskiego, tradycja i rola pieśni czeskiej mogły być więc w Polsce znane.

Pojawia się pytanie, jakie jeszcze czynniki przemawiają za taką rolą środowiska gnieźnieńskiego.Zwróćmy uwagę na tradycję wiążącą Bogurodzicę ze świętym Wojciechem, która musiała mieć jakieś podłoże. Przypomnijmy, iż w pierwszej fazie umacnianiu poczucia narodowościowego J. Świnka położył nacisk na kult św. Wojciecha. Nieco później polska hierarchia kościelna będzie aktywnie promować Bogurodzice, nadając odpusty za jej śpiewanie czy też słuchanie - w zachowanym graduale maryjnym z początku XVI w. znajduje się adnotacja o odpustach (czterdziestodniowych) przyznanych około połowy XV w. przez biskupów: włocławskiego, krakowskiego, przemyskiego i kamienieckiego oraz - co już jest częścią legendy o św. Wojciechu ,autorze” pieśni - samego męczennika. Badacze przypuszczają, że brak wzmianki o arcybiskupie gnieźnieńskim wiąże się z założeniem, że odpustu udzielił św. Wojciech, wedle legendy poprzednik na stolcu arcybiskupim ${ }^{162}$. Sądzę jednak, iż wytłumaczenie może być inne: arcybiskup gnieźnieński, zainteresowany rozpowszechnieniem pieśni, podobne kroki podjął znacznie wcześniej. Nie będziemy tu omawiać wszystkich przejawów owej świętowojciechowej tradycji, które wyczerpująco nakreślił Wiesław Wydra, zastanówmy się jednak nad przyczyną tego powiązania, w którym upatrywano już zresztą dawno tradycję gnieźnieńską ${ }^{163}$. Nader prawdopodobne wyjaśnienie przytacza przywołany W. Wydra, który również dochodzi do wniosku o jej łączności z Gnieznem, gdzie kult św. Wojciecha był najsilniejszy: mianowicie była ona zapewne często tu wykonywana, stąd pielgrzymom do grobu św. Wojciecha skojarzyła się z męczennikiem uchodzącym za pierwszego arcybiskupa, patrona narodu i państwa. Skoro w Czechach przypisywano mu pieśń Hospodine, blisko stąd do przyjęcia, iż musiał stworzyć podobną pieśń dla Polski, co wspierać mogły niezrozumiałe już u schyłku XV czy w początku XVI w. słowa, traktowane być może jako

159 Szerzej ostatnio R. Antonín, Zahraniční politika krále Václava II. v letech 1283-1300, Brno 2009, s. 209 nn.

${ }^{160}$ W. Karasiewicz, op. cit., s. 343; K. Kantak, op. cit., t. 1, s. 377.

161 Přiběhy krále Přemysla, s. 319 pod 1260 r.; por. Pokračovatelé Kosmovi, Praha 1974, s. 129; Z. Nejedlý, op. cit., s. 242.

162 Bogurodzica, s. 115; W. Wydra, Dzieje, s. 197.

163 Tak np. J. Birkenmajer, Zagadnienie, s. 9. 
czechizmy ${ }^{164}$. Jak więc widzimy, wszystkie okoliczności zdają się wieść do Gniezna.

Koronnym argumentem badaczy wskazujących na późne powstanie pieśni jest milczenie źródeł o jej wykonywaniu. Zauważmy jednak, iż potencjalna inicjatywa abp. Świnki, zrealizowana przez duchownego obeznanego z twórczością czeską, a zapewne i tradycją zachodnią w tym zakresie, zaowocowała dziełem o wybitnym kunszcie artystycznym i, co zgodnie podkreślają badacze, trudnej melodii ${ }^{165}$. Wskazuje się, że była przeznaczona do wykonywania przez wyszkolony chór. Czynniki te nie sprzyjały niewątpliwie szybkiemu jej upowszechnieniu, jednak - jak już wspominano - znajomość pieśni wśród rycerstwa w początku XV w. i określenie jej przez Długosza jako carmen patrium musiało wynikać z jej dłuższej obecności w życiu liturgicznym, a może i państwowym. Nie musiała to być jedyna droga. Kościół, jak mało która instytucja, miał środki i możliwości szerokiego oddziaływania na społeczeństwo. Nie tylko przez obrzędy liturgiczne, podczas których lud wysłuchiwał kazań, często z elementami historycznymi, służącymi kształtowaniu określonych postaw ${ }^{166}$, nie tylko za pomocą napomnień i wskazówek, nie tylko poprzez śpiewanie pieśni, ale też przez kolejny element - szkolnictwo kościelne, które mogło służyć jako instrument propagandy i szerzenia określonych treści w celu pogłębienia świadomości narodowej ${ }^{167}$ i konsolidacji społeczeństwa wokół wspólnych wartości: tak religijnych, jak i językowych, narodowych czy państwowych. Tymi więc drogami pieśń początkowo elitarna, przeznaczona dla wyszkolonych śpiewaków, mogła dotrzeć najpierw do warstw górnych społeczeństwa, z czasem zaś i niżej, stając się pieśnią ludową. Jak trafnie zauważył W. Drelicharz, w odniesieniu do upowszechniania znajomości legendy św. Wojciecha zastosowano tu nowoczesny sposób myślenia o formie komunikowania masowego: najpierw dotarcie z określonymi treściami do duchownych, którzy mogli je rozpowszechniać wśród ludu ${ }^{168}$.

${ }^{164}$ W. Wydra, Dzieje, s. 197 n. Również Henryk Fros (op. cit., s. 135) przypuszczał, iż związek świętego z Bogurodzica wiązał się z uroczystościami na cześć męczennika w Gnieźnie, podczas których ją śpiewano. Zauważmy, że nawet kopiści najstarszego kodeksu mieli problem z rozumieniem słów, zob. M. A. Janicki, Bogurodzica, s. 177 n.

165 J. Woronczak, Wstęp filologiczny, s. 15; S. Urbańczyk, „Bogurodzica”, s. 147; J. Okoń, op. cit., s. $708 \mathrm{n}$.

${ }^{166}$ R. Heck, Problemy świadomości historycznej średniowiecznego społeczeństwa polskiego, w: Dawna świadomość historyczna w Polsce, Czechach i Słowacji, red. idem, Wrocław 1978, s. 52, 60.

${ }^{167}$ Por. ibidem, s. 58 nn.; B. Nowacki, Arcybiskup, s. 118.

168 W. Drelicharz, op. cit., s. 262. 
Jest też drugi istotny czynnik, mogący wpływać na brak szerszego rozpropagowania pieśni w XIV w. Zauważmy, że choć Bogurodzica związana była ze środowiskiem gnieźnieńskim, to jednak po zjednoczeniu centrum życia politycznego przeniosło się do Krakowa, gdzie duchowieństwo niewątpliwie zazdrośnie strzegło roli św. Stanisława, nowego patrona zjednoczonego królestwa. Stąd pieśń mogła, jak podnosi W. Wydra, czas jakiś wieść „cichy, spokojny żywot” ${ }^{169}$, co nie znaczy oczywiście, iż nie była stopniowo rozpowszechniana wśród społeczeństwa.

Podsumujmy dotychczasowe rozważania. Potrzeba ochrony Kościoła polskiego, głębszej integracji społeczeństwa polskiego czy w istocie jego narodu politycznego w okresie zatargów narodowościowych i nieustannych konfliktów zewnętrznych oraz rozbicia dzielnicowego, mogła budzić zapotrzebowanie na uniwersalną ochronę i, jak sądzę, mogła leżeć u podłoża powstania Bogurodzicy. Pieśń ta łączyła bowiem dwa ważne pierwiastki: włączenie uniwersalnego kultu św. Maryi i św. Jana Chrzciciela do umacniania integralności narodu (wobec istnienia rywalizujących ośrodków i kultów dzielnicowych) oraz propagowanie języka polskiego. Stąd zasadna wydaje się hipoteza, że Bogurodzica mogła powstać w środowisku gnieźnieńskim na przełomie XIII/XIV w., z inspiracji abp. Świnki na tle jego działalności w obronie języka polskiego i rozwijanej ideologii zjednoczeniowej. Jak już zauważono, w realizacji swoich celów politycznych potrafił on posługiwać się różnorodnymi narzędziami, tak tradycyjnymi, jak i zupełnie nowatorskimi na gruncie polskim ${ }^{170}$. W zakresie datacji można by pokusić się o dalsze doprecyzowanie: skoro jeszcze w latach osiemdziesiątych XIII w. próbowano w Gnieźnie uruchomić w roli zjednoczeniowej i scalającej kult św. Wojciecha, jak wskazują Miracula św. Wojciecha oraz omawiane statuty, a w statutach tych propaguje się już język polski, ale brak śladów pierwszej polskiej pieśni religijnej, należałoby jej powstanie przesunąć na pierwsze dziesięciolecie XIV w. Zauważmy też, że jakkol-

${ }^{169}$ W. Wydra, Es ist, s. 81.

170 W. Drelicharz, op. cit., s. 260 n.; por. szerzej K. Skupieński, Miejsce notariatu publicznego wśród środków realizacji programu politycznego arcybiskupa Jakuba Świnki, KH 96, 1989, 3-4, s. 63-84. Jako oddźwięk propolskiej działalności J. Świnki (określanego tu mianem „ukrytego animatora”) W. Wydra interpretuje ostatnio powstanie Kazań świętokrzyskich, kolejnego zabytku w języku polskim, która to teza również uwzględnia tło w postaci konfliktów narodowościowych, zob. W. Wydra, Wokót fenomenu Kazań świętokrzyskich, w: Kazania świętokrzyskie. Nowa edycja, nowe propozycje badawcze, red. P. Stępień, Warszawa 2009, s. 53 n. Badacz ten zwraca też uwagę, iż za tym zabytkiem, datowanym na schyłek XIII w. lub przełom XIII/XIV w. (w zachowanej postaci z początku XIV w., ibidem, s. 45, 47, 53), kryje się skryptorium, które już od jakiegoś czasu „wprawnie” używało pisma w języku polskim (ibidem, s. 52 n.), co zdaje się również dodatkowo przemawiać na rzecz naszego datowania Bogurodzicy. 
wiek wśród inspiracji dostrzec można pierwiastki zaczerpnięte z kultury łacińskiej i pośrednio bizantyńskiej, to jednak ważnym wzorcem naszej pieśni musiało być - jak już przypuszczano - piśmiennictwo czeskie, zwłaszcza pieśń Hospodine pomiluj ny, której ideologiczna funkcja na obszarze czeskiego życia państwowego mogła zostać dostrzeżona i wykorzystana przez polskich inicjatorów powstania Bogurodzicy do stworzenia własnego, swoistego „hymnu państwowego”.

\section{Carmen patrium Bogurodzica - Time of Origin, Historical Context and Inspirations}

Bogurodzica is indubitably one of the most controversial and longest discussed monuments of Polish-language mediaeval literature. The article intends to once again establish the time of the song's origin and the factors, which influenced the latter. An analysis of the socio-political situation at the end of the thirteenth century made it possible to indicate that those factors entailed in all probability the necessity to protect the Polish language, the Church, and a more profound integration of Polish society at a time of nationality clashes, incessant external conflicts, and a feudal fragmentation of the state into provinces. Those circumstances could have given rise to a need for universal religious support, expressed by the text of Bogurodzica. The song consolidated the universal cult of the Mary, Mother of God, and John the Baptist and thus could strengthen the integrity of the nation in the course of national conflicts (and a tangible threat posed by German-speaking incomers); finally, in the Bohemian mode, it constituted a sui generis national anthem. These are the reasons for a hypothesis claiming that Bogurodzica could have originated within the Gniezno milieu at the turn of the thirteenth century, and was inspired by Archbishop Jakub Świnka, against the backdrop of his activity as a defender of the Polish language and the unification ideology developed at the time. Although the potential sources include discernible elements borrowed from Latin and, indirectly, Byzantine culture the prominent sources must have been Bohemian (and, indirectly, Old Slavonic) writings. The stimulus in question was, as has been indicated, predominantly the song: Hospodine pomiluj ny, whose ideological function within Bohemian state life could have been noted by the Polish authors of Bogurodzica.

Translated by Aleksandra Rodzińska-Chojnowska 